\title{
Divorcing Sexual Harassment from Sex: Lessons from the French
}

\author{
L. CAMILLE HÉBERT*
}

INTRODUCTION

One of the challenges in establishing the existence of actionable sexual harassment under Title VII of the Civil Rights Act of $1964^{1}$ has been to prove that the harassing conduct, even when it is explicitly sexual, has occurred "because of ... sex" - a requirement for actionable sexual harassment. Because sexual harassment in the context of the American workplace is prohibited as a form of discrimination on the basis of sex, harassment that is not seen as fitting within the framework of sex discrimination is not generally considered to be unlawful. ${ }^{2}$ Accordingly, the courts have insisted that the harassment to which targets are subjected be shown to have been motivated by the sex or gender of that target, ${ }^{3}$ and not by other considerations, such as actual or perceived sexual orientation ${ }^{4}$

Copyright (C) 2014 by L. Camille Hébert

* Carter C. Kissell Professor of Law, Michael E. Moritz College of Law at the Ohio State University. I wish to acknowledge the support of the Center for Interdisciplinary Law and Policy Studies at the Michael E. Moritz College of Law of The Ohio State University, which provided research funding for this project, and particularly its director, Professor Katherine Federle. I also want to thank Isabelle Daugareilh and Loïc Lerouge of COMPTRASEC, the Centre de Droit Comparé du Travail et de la Sécurité Sociale (Centre for Comparative Labour and Social Security Law) at the Université Montesquieu-Bordeaux IV, France, for their hospitality during my research stay and their helpfulness in facilitating my research of French law of moral and sexual harassment.

1. 42 U.S.C. § 2000e-2000e-17 (2006 \& Supp. 2010).

2. It is true that the harassing conduct that is not considered to be based on sex might violate other legal prohibitions, such as the tort restrictions on assault and battery or intentional infliction of emotional distress, but harassing conduct that is not considered to be based on sex does not violate Title VII's prohibition on sexual harassment.

3. In Oncale v. Sundowner Offshore Services, Inc., 523 U.S. 75 (1998), the United States Supreme Court stressed:

Title VII does not prohibit all verbal or physical harassment in the workplace; it is directed only at "discriminat[ion]... because of ... sex." We have never held that workplace harassment, even harassment between men and women, is automatically discrimination because of sex merely because the words used have sexual content or connotations. "The critical issue, Title VII's text indicates, is whether members of one sex are exposed to disadvantageous terms or conditions of employment to which members of the other sex are not exposed."

Id. at 80 (emphasis in original) (quoting Harris v. Forklift Sys., Inc., 510 U.S. 17, 25 (1993) (Ginsburg, J., concurring)).

4. In the United States, discrimination on the basis of sexual orientation is generally not prohibited as a matter of federal law, because it is not expressly prohibited, nor is it considered to be a form of sex discrimination under Title VII, and is prohibited in only a minority, though a growing number, of states. See L. CAMILLE HÉBERT, EMPLOYEE PRIVACY LAW 9-4 - 9-434 (Thomson Reuters 2012) (reviewing the history and attempted justifications of discrimination on the basis of sexual orientation, as well as case law and statutory authority related to such discrimination, including challenges under Title VII of the Civil Rights Act of 1964, which have been rejected by most courts; 
or simple personal dislike. Accordingly, in a number of cases of both oppositesex and same-sex harassment, courts have concluded that explicitly sexually denigrating conduct was not motivated by sex, and therefore was not prohibited by Title VII. ${ }^{5}$

I have explained elsewhere my concerns about the questionable analysis that has caused courts to conclude that explicitly sexually denigrating conduct is not based on sex, ${ }^{6}$ and I will not repeat those arguments here. However, my concerns about those holdings have caused me to explore the possibility of a law of sexual harassment divorced from the "because of ... sex" requirement-a prohibition against sexual harassment in the workplace that does not require a showing that the harassment was motivated by sexual desire, gender hostility, or sexual stereotyping, or constituted explicitly different activity directed at men and women. ${ }^{7}$

This possibility, while foreign to the conception of sexual harassment law in

also reviewing discrimination on the basis of sexual orientation in the states).

5. See L. Camille Hébert, Sexual Harassment as Discrimination "Because of . . Sex": Have We Come Full Circle?, 27 OHIO N.U. L. REV 439, 457-80 (2001) (reviewing cases in which lower courts applied the "because of. . sex" requirement and came to different conclusions about the motivations of the accused harassers).

6. Hébert, supra note 5, at 480-83; L. Camille Hébert, Sexual Harassment is Gender Harassment, 43 U. KAN. L. REV. 565, 573-76 (1995) [hereinafter Gender Harassment].

7. While these may not be the only ways in which to prove that harassment occurred "because of ... sex," these are the ways in which the courts, particularly the U.S. Supreme Court, have indicated that discrimination based on sex can be shown. In Oncale, 523 U.S.at 80-81, the Court indicated that harassment could be shown to be based on sex in the following manner:

Courts and juries have found the inference of discrimination easy to draw in most malefemale sexual harassment situations, because the challenged conduct typically involves explicit or implicit proposals of sexual activity; it is reasonable to assume those proposals would not have been made to someone of the same sex. The same chain of inference would be available to a plaintiff alleging same-sex harassment, if there were credible evidence that the harasser was homosexual. But harassing conduct need not be motivated by sexual desire to support an inference of discrimination on the basis of sex. A trier of fact might reasonably find such discrimination, for example, if a female victim is harassed in such sexspecific and derogatory terms by another woman as to make it clear that the harasser is motivated by general hostility to the presence of women in the workplace. A same-sex harassment plaintiff may also, of course, offer direct comparative evidence about how the alleged harasser treated members of both sexes in a mixed-sex workplace. Whatever evidentiary route the plaintiff chooses to follow, he or she must always prove that the conduct at issue was not merely tinged with offensive sexual connotations, but actually constituted "discrimina[tion] . . because of . . . sex."

Id. at 80-81. And in Price Waterhouse v. Hopkins, 490 U.S. 228 (1989), a majority of the members of the Court acknowledged that acting on the basis of sexual stereotypes constituted discrimination on the basis of gender. Id. at 250 ("In the specific context of sex stereotyping, an employer who acts on the basis of a belief that a woman cannot be aggressive, or that she must not be, has acted on the basis of gender."); Id. at 272-73 (O'Connor, J., concurring) (characterizing evidence of reliance on sex stereotyping as evidence of discriminatory intent with respect to challenged employment decision). Even the dissent in the Price Waterhouse case acknowledged that "[e]vidence of use by decisionmakers of sex stereotypes is, of course, quite relevant to the question of discriminatory intent." Id. at 294 (Kennedy, J., dissenting).

I do not mean to suggest that sexually explicit denigrating conduct is not in fact based on one of these motivations or otherwise not based on sex, only that so many courts have reached the contrary conclusion that alternatives methods of establishing the existence of actionable sexual harassment may avoid the difficulties that plaintiffs often have in convincing courts of the unlawfulness of the conduct directed against them. 
the United States, ${ }^{8}$ is consistent with the law in a number of jurisdictions outside the United States. A number of those jurisdictions prohibit both sexual harassment and "moral harassment." Prohibited sexual harassment is generally defined as involving conduct that is sexual in nature, although the harm sought to be prevented is not focused on discrimination so much as on harm to dignity. ${ }^{9}$ Claims of moral harassment seek to regulate derogatory or denigrating workplace conduct more generally, reaching beyond conduct that is sexual in nature or discriminatorily motivated. Although the precise definition of moral harassment differs among jurisdictions, the jurisdictions that recognize such a claim generally define the prohibited conduct as conduct directed at a subordinate or co-worker that has the purpose or effect of injuring the dignity of that employee or adversely affecting his or her employment conditions or opportunities. ${ }^{10}$ In those jurisdictions, a showing of actionable harassment does

8. Courts in the United States have expressed concern that prohibiting harassment independent of a discriminatory motivation would turn Title VII into a "general civility code." See, e.g., Oncale, 523 U.S. at 80 ("Respondents and their amici contend that recognizing liability for samesex harassment will transform Title VII into a general civility code for the American workplace. But that risk is no greater for same-sex than for opposite-sex harassment, and is adequately met by careful attention to the requirements of the statute."); Faragher v. City of Boca Raton, 524 U.S. 775, 788 (1998) ("These standards for judging hostility are sufficiently demanding to ensure that Title VII does not become a 'general civility code.' Properly applied, they will filter out complaints attacking 'the ordinary tribulations of the workplace, such as the sporadic use of abusive language, gender-related jokes, and occasional teasing.'") (citations omitted). Similar concerns have been expressed by the lower courts. See, e.g., Terry v. Texas Dep't of Criminal Justice, 2010 WL 3860369, *2 (E.D. Tex. 2010) ("Title VII is not a federal general civility code or a general prohibition against all bad acts."); Wilson v. U.S. Dep't of Transportation, 759 F. Supp. 2d 55, 67 (D.D.C. 2011) (“Title VII is not a civility code."). The courts have not, however, adequately explained the dangers or risks of a requirement of civility in the workplace.

9. See, for example, Belgium's prohibition on sexual harassment, which prohibits: "all types of verbal, non-verbal, or physical behavior of a sexual nature, which the guilty party knows or should know will affect the dignity of women and men in the workplace." Loi relative à la protection contre la violence et le harcèlement moral ou sexuel au travail [Law Concerning Protection against Violence and Moral or Sexual Harassment at Work] of June 11, 2002, MONITEUR BELGE [MB] [Official Gazette of Belgium], June 22, 2002, 28521. This is an unofficial translation by the author of the original French: « toute forme de comportement verbal, non-verbal ou corporel de nature sexuelle, dont celui qui s'en rend coupable, sait ou devrait savoir, qu'il affecte la dignité de femmes et d'hommes sur les lieux de travail ». Unless otherwise indicated, all translations offered in this article are unofficial translations by the author.

10. Belgium's prohibition on moral harassment prohibits "abusive and repeated conduct, from sources external or internal to the enterprise or institution, that are manifested particularly in behavior, words, threats, actions, gestures, or unilateral writings, having the purpose or effect of harming the personality, the dignity, or the physical or psychological integrity of a worker or other person to whom the present chapter applies, during the execution of his or work, and putting in danger his or work or creating an intimidating, hostile, degrading, humiliating, or offensive environment." Id. In the original French: « les conduites abusives et répétées de toute origine, externe ou interne à l'entreprise ou l'institution, qui se manifestent notamment par des comportements, des paroles, des intimidations, des actes, des gestes et des écrits unilatéraux, ayant pour objet ou pour effet de porter atteinte à la personnalité, la dignité ou l'intégrité physique ou psychique d'un travailleur ou d'une autre personne à laquelle le présent chapitre est d'application, lors de l'exécution de son travail, de mettre en péril son emploi ou de créer un environnement intimidant, hostile, dégradant, humiliant ou offensant ».

For a discussion of Belgium's law concerning moral harassment, see Loïc Lerouge, Moral Harassment in the Workplace: French Law and European Perspectives, 32 COMP. LAB. L. \& POL'Y J. 109, 137-43 (2010) 
not require that the harassment be shown to have been inflicted with a discriminatory motive or effect, but merely requires a showing of either intent to harm or sufficient injury.

This article will explore whether recognition of a claim of sexual harassment focused on dignity rather than discrimination, or even of a gender-neutral claim of harassment, similar to a claim of moral harassment in France, might be possible within the scope of the American legal system, either as a substitute for, or a supplement to, the presently recognized claim of discriminatory harassment under Title VII. In so doing, this article will explore the historical and cultural differences that have led to the development of these disparate approaches in the United States and in France, as well as the challenges that would have to be faced in attempting to import aspects of such a discrimination-neutral or genderneutral claim of harassment into the law of the United States.

\section{FRANCE'S LAW OF SEXUAL AND MORAL HARASSMENT}

The current state of the law with respect to sexual and moral harassment in France reflects the historical development of that law within France, including some quite recent events, as well as the influence of the requirements imposed on France and French law by its membership in the European Union. Because the theoretical basis for harassment law as it originally developed within French law differs from the basis for harassment law as required to be incorporated into French law by European Union directives, there appear to be two distinct types of both sexual harassment and moral harassment recognized in French law. In addition, the law concerning sexual harassment and the law concerning moral harassment still differ substantially from each other, in spite of some attempts to harmonize those different laws.

\section{A. The Prohibitions of Sexual Harassment}

The prohibitions of sexual harassment appear in both the Penal Code (Code Pénal) and the Labor Code (Code du Travail). France's original provision concerning sexual harassment was enacted in 1992,11 as part of the Penal Code, and amended in $1998,{ }^{12}$ so that the prohibition read as follows:

The fact of harassing others by issuing orders, uttering threats, using force, or exerting serious pressure, with the goal of obtaining favors of a sexual nature by a person abusing the authority granted by his or her duties, is punishable by a term of one year's imprisonment and a fine of 100,000 francs. ${ }^{13}$

[hereinafter Moral Harassment in the Workplace].

11. Loi 92-684 du 22 juillet 1992 portant réforme des dispositions du code pénal relatives à la répression des crimes et délits contre les personnes [Law 92-684 of July 22, 1992 concerning the reform of the penal code relative to the prosecution of crimes against persons], JOURNAL OFFICIEL DE LA REPUbliQue FrANÇAise [J.O.] [OFFICIAL GAZETTE OF FRANCE], July 23, 1992, p. 9875.

12. Loi 98-468 du 17 juin 1998 relative à la prévention et à la répression des infractions sexuelles ainsi qu'à la protection des mineurs [Law 98-468 of June 17, 1998 on the prevention and punishment of sexual offenses and the protection of minors], JOURNAL OFFICIEL DE LA REPUBLIQUE FRANÇAISE [J.O.] [OFFICIAL GAZETTE OF FRANCE], June 18, 1998, p.9255.

13. This is an unofficial translation by the author of the original French: « Le fait de harceler autrui en donnant des ordres, proférant des menaces, imposant des contraintes ou exerçant des 
A similar provision was included in the French Labor Code in 1992. That provision originally provided that:

No employee shall be sanctioned or dismissed for having submitted or having refused to submit to acts of harassment from an employer, from its representative, or from any person who, by abusing his or her authority conferred by his or her duties, has given orders, made threats, imposed force, or exercised pressure of any nature on the employee with the goal of obtaining favors of a sexual nature for his or her benefit or the benefit of a third party. ${ }^{14}$

By their terms, these provisions characterized sexual harassment as acts motivated by the goal of "obtaining favors of a sexual nature," rather than by some other purpose, and restricted harassment to actions taken by a person abusing his or her authority, thereby prohibiting sexual harassment only when it occurred within a system of hierarchy, such as that existing between a superior and a subordinate within the context of the workplace. ${ }^{15}$ The focus of these provisions on the abuse of authority through specified types of coercive action and the goal of obtaining sexual "favors," as well as the placement of the Penal Code provision in the portion of the code addressing forms of sexual violence and aggression, including rape, suggests that the basis of these original provisions was to protect women from sexual coercion, whether that coercion was accomplished by physical or other types of constraints. ${ }^{16}$

The cases decided under this version of the sexual harassment provisions indicate that the existence of coercion, including both promises of benefits and threats of harm, was an essential aspect of a claim of sexual harassment. In a decision by the criminal division of the Court of Cassation (Cour de cassation, chamber criminelle), the highest court in the French judiciary, ${ }^{17}$ the court upheld

pressions graves dans le but d'obtenir des faveurs de nature sexuelle, par une personne abusant de l'autorité qui lui confèrent ses fonctions, est puni d'un an d'emprisonnement et de $100000 \mathrm{~F}$ d'amende. » CODE PÉNAL [C. PEN.] art. 222-33 (version in effect from June 18, 1998, to Jan. 1, 2002).

14. Loi 92-1179 du 2 novembre 1992 relative à l'abus d'autorité en matière sexuelle dans les relations de travail et modifiant le code du travail et le code de procédure pénale [Law 92-1179 of November 2, 1992 on the abuse of power in sexual matters in employment relationships and modification of the labor code and code of criminal procedure] ; JOURNAL OFFICIEL DE LA REPUBLIQUE FRANÇAISE [J.O.] [OFFICIAL GAZETTE OF FRANCE], Nov. 4, 1992, p.15255, art. L. 122-46.. In the original French : "Aucun salarié ne peut être sanctionné ni licencié pour avoir subi ou refusé de subir les agissements de harcèlement d'un employeur, de son représentant ou de toute personne qui, abusant de l'autorité que lui confèrent ses fonctions, a donné des ordres, proféré des menaces, imposé des contraintes or exercé des pressions de toute nature sur ce salarié dans le but d'obtenir des faveurs de nature sexuelle à son profit ou au profit d'un tiers. »

15. Id.

16. See Conseil constitutionnel [CC] [Constitutional Court], Commentaire, decision No. 2012-240 QPC, May 4, 2012, 2-3, available at http://www.conseil-constitutionnel.fr/conseilconstitutionnel/root/bank/download/2012240QPCccc_240qpc.pdf (discussing the placement of the prohibition on sexual harassment in the section of the Penal Code dealing with sexual aggression and other offenses committed with moral or physical constraints).

17. The function of the Court of Cassation is to review decisions of the lower courts in order to determine whether those decisions have accurately applied the law to the facts of those cases. The Court does not resolve the merits of a dispute but generally proclaims whether the lower court decision is in compliance with the law, in which case it is accepted, or not in compliance with the law, in which case it is rejected and generally returned to the lower court. Cour de cassation, About the Court, COURDECASSATION.FR, http://www.courdecassation.fr/about_the_court_9256.html (last 
the decision of the court of appeals concluding that sexual harassment had occurred based on both promises of benefits if the target of harassment had sex with her supervisor, and also threats of disadvantage if she continued to refuse; the court of appeals had found sexual harassment to have been established even though the target of harassment had continued to progress in her career at the company in spite of her refusal to submit to the harasser's sexual advances, noting that the harasser had intended to keep her in his service in order to achieve his goals of obtaining sexual acts from her. ${ }^{18}$ Similarly, in another decision, the criminal division of the Court of Cassation upheld the lower court's conclusion that a manager had engaged in sexual harassment by giving a subordinate a promotion when she agreed to have sex with him and then relegating her to cleaning toilets when she refused to continue the relationship. ${ }^{19}$

Some courts seem to have interpreted the concept of the coercive action required to prove sexual harassment quite broadly, to include abusive action by the harasser aimed at accomplishing the submission to sexual acts by the target of harassment. For example, the Court of Appeals of Paris held that acts of harassment could include, in addition to touching imposed on an employee, words spoken with the object of obtaining sexual acts, including professional and sexual denigration and threats, insults, and abuse of all kinds uttered in the event of a refusal to grant sexual favors. ${ }^{20}$

Conversely, the absence of coercion, even when unwanted sexual advances occurred in the context of a hierarchical workplace relationship, was deemed fatal to a sexual harassment claim. Accordingly, in another case, the criminal division of the Court of Cassation upheld the court of appeals' dismissal of claims of sexual harassment against a manager who was found to have made repeated sexual advances to a subordinate in whom the court noted he had a sexual interest, including "forgetting" to rent a second hotel room on a business trip and therefore inviting her to share his single bed. ${ }^{21}$ The court of appeals had noted the absence of "blackmail" and had indicated that "an attitude of seduction, even devoid of tact and delicacy, does not constitute the offense of harassment, no more than simple conventional social signals initiated in a fashion to express the demonstration of an inclination."22 This case seems to

visited October 6, 2013). The English translation of the word "cassation," in the context of a decision or a judgment, is "annulment" or "quashing." HARRAP'S DICTIONNAIRE JURIDIQUE, FRANÇAISANGLAIS 19 (Dalloz 2004).

18. Cour de cassation [Cass.] [supreme court for judicial matters] crim., Nov. 20, 2002, No. $02-$ 81.635, available

http://www.legifrance.gouv.fr/affichJuriJudi.do?oldAction=rechExpJuriJudi\&idTexte=JURITEXT00 0007602905\&fastReqId=1375350769\&fastPos=1 (concerning acts of harassment occurring between 1995 and 1999).

19. Cour de cassation [Cass.] [supreme court for judicial matters] crim., Feb. 18, 2004, No. 0383.302, available

http:/ / www.legifrance.gouv.fr/affichJuriJudi.do?oldAction=rechExpJuriJudi\&idTexte=JURITEXT00 $0007614704 \&$ fastReqId $=525365472 \&$ fastPos $=1$ (concerning acts of harassment occurring between 1995 and 1997).

20. Cour d'Appel[CA] [regional court of appeal] Paris, 18 e ch.., 18 Jan. 1996, reported in Michel Miné \& Francis Saramito, Le harcèlement sexuel, DROIT OUVRIER, Février 1997, at 76-77 .

21. Id.

22. Cour de cassation [Cass.] [supreme court for judicial matters] crim., Jan. 19, 2005, No. 04- 
confirm the terms of the statute that it was not enough that the advances and other conduct be unwanted and without the consent of the target of harassment; instead, this version of the prohibition on sexual harassment required some showing of coercion, whether physical, psychological, or economic.

The use of the term "harassment" (harcèlement) in the prohibition of sexual harassment raised a question whether the actions on which a claim was based had to be repeated in order to be unlawful under the statute, even though the discussion in the Senate at the time the term "harassment" was added to the Penal Code provision indicated that the legislators anticipated that even a single act could constitute actionable harassment. ${ }^{23}$ In fact, some objection was made to the use of that term as being insufficiently precise because the dictionary definition of the French verb "harceler» (to harass) included the concept of repetition. ${ }^{24}$ That term was apparently adopted in spite of this objection because of the general acceptance of that term to describe the offense being prohibited. ${ }^{25}$ It is not entirely clear how, or whether, this issue was resolved by the judiciary in applying the statute. The court of appeals, in at least one case involving an employee who contended that she was discharged for reporting a single act of

83.443,

available

http://www.legifrance.gouv.fr/affichJuriJudi.do?oldAction=rechExpJuriJudi\&idTexte=JURITEXT00 0007611862\&fastReqId=1538106140\&fastPos=1 (concerning events occurring in 2000). In the original French : «une attitude de séduction même dénuée de tact ou de délicatesse ne saurait constituer le délit de harcèlement, pas davantage que de simples signaux sociaux conventionnels lancés de façon à exprimer la manifestation d'une inclination ».

23. See Sénat, Première Session Ordinaire de 1991-1992, Séance du jeudi 3 octobre 1991, Débats Parlementaires, JOURnAl OFFICIEL DE LA REPubliQue FrançAise [J.O.] [OFFICIAL GAZETTE OF FRANCE], Oct. 3, 1991, at 2627-28 (discussion suggesting that single act, such as sexual blackmail, would be sufficient to state a claim of harassment under proposed provision). See also Damien Roets, L'Inquiétante métamorphose du délit de harcèlement sexuel, 26 RECUEIL DALLOZ 2059 (2002) (noting that the parliamentary debate revealed that the intent of the legislators was to permit a finding of harassment from a single act, but also that the verb " harceler » generally connotates repetition); Françoise Dekeuwer-Defossez, Le harcèlement sexuel en droit français : discrimination ou atteinte à la liberté ?, LA SEMAINE JURIDIQUE, ÉD. G., 1993, no. 13, at 3662 (indicating that it was clearly stated in the parlimentary debates that a sufficiently serious single act, such as blackmail, would qualify as sexual harassment, and that the term "harcèlement sexuel," as a French translation of the anglo-saxon term "sexual harassment," was chosen for its power of evocation rather than for its semantic precision).

24. Sénat, Première Session Ordinaire de 1991-1992, Séance du jeudi 3 octobre 1991, Débats Parlementaires, JOURNAL OfFICIEL DE LA REPUbliQue FrANÇAISE [J.O.] [OFFICIAL GAZETTE OF FRANCE], Oct. 3, 1991, p. 2627 (discussing the appropriateness of using the term « harcèlement, " noting that the dictionary Robert defines the term " harceler » to mean : "to torment, to subject without respite to repeated attacks, to fast, constant assaults" /In French: " tourmenter, soumettre sans répit à des attaques réitérées, à de rapides assauts incessants »).

25. Id. (statement of M. Charles Jolibois, indicating that notion of sexual harassment was known and that "it is indisputable that we should use the term "to harass."/In French: «il faut incontestablement utiliser le mot " harceler ».) Even those who opposed use of the term "harcèlement" noted the general use of that term to describe the offense being prohibited. See id. (statement of M. Michel Dreyfus-Schmidt that "what all the world calls sexual harassment must be punished" / In French: « ce que tout le monde appelle le harcèlement sexuel doit être puni »).

Interestingly, in spite of the fact that the origin of the English verb "harass" is French, neither the dictionary definition of the term, nor the common understanding of the term, is tied so directly to the concept of repetition, at least in the United States. See THE NEW OXFORD AMERICAN DICTIONARY 773 (Elizabeth J. Jewell \& Frank Abate eds., Oxford University Press 2001) (the "core sense" of the word "harass" is "subject to aggressive pressure or intimidation," while the "subsense" of the word is "make repeated small-scale attacks on (an enemy)"). 
harassment of another, concluded that "the law establishes that harassment results from a repetition of acts and does not correspond to a single act." 26 Most cases, however, did not state any such requirement, although it is also true that most litigated cases of sexual harassment did in fact involve repeated acts. ${ }^{27}$

In 2002, as part of the Social Modernization Act, ${ }^{28}$ the Penal Code provision on sexual harassment was modified to remove the requirements that the harassment occur by certain types of coercive actions and by a person abusing his or her authority, so that the law simply provided that:

The fact of harassing another person with the goal of obtaining favors of a sexual nature shall be punished by a term of one year's imprisonment and a fine of 15,000 euros. $^{29}$

Similarly, after changes made by the Social Modernization Act and the recodification of the Labor Code, the provision on sexual harassment, then contained in Art. L. 1153-1 of the French Labor Code, merely provided:

Acts of harassment by all persons with the goal of obtaining sexual favors for one's benefit or the benefit of a third party are prohibited. ${ }^{30}$

The apparent purpose of this change was to broaden the definition of sexual harassment to ensure that these provisions were not limited to harassment accomplished by an abuse of authority and to harmonize the sexual harassment provisions of the Penal Code with the sexual harassment provisions contained in the Labor Code, as well as to harmonize the sexual harassment provisions in both codes with the newly enacted provisions on moral harassment in both codes. ${ }^{31}$ The effect of this change was to no longer require that the harassment occur within the context of a hierarchical relationship, but the amendment also removed the express requirements that the harassment be accomplished by use of coercive actions. It is unclear whether this change was intended to remove all requirement of coercion from a claim of sexual harassment or, instead, to broaden the notion of the types of constraints that might be used in order to

26. Cour d'appel [CA] [regional court of appeal] Angers, soc., June 7, 2011, No. 10/01241, available at http://legimobile.fr/fr/jp/j/ca/49007/2011/6/7/10_01241/. In the original French : «La jurisprudence, cependant, établit que le harcèlement résulte d'une répétition de faits et ne correspond pas à un acte unique. »

27. See Roets, supra note 23 (noting that the law has not been clearly settled on this point, but that most cases involved repeated acts of harassment).

28. Loi 2002-73 du 17 janvier 2002 de modernisation sociale [Law 2002-73 of January 17, 2002 of social modernization], JOURNAL OFFICIEL DE LA REPUBLIQUE FRANÇAISE [J.O.] [OFFICIAL GAZETTE OF FRANCE], Jan. 18, 2002, p. 1008.

29. In the original French: « Le fait de harceler autrui dans le but d'obtenir des faveurs de nature sexuelle est puni d'un an d'emprisonnement et de $15000 €$ d'amende. » CODE PÉNAL [C. PEN.] art. 222-33 (version in effect from Jan. 18, 2002, to Feb. 10, 2010).

30. CODE DU TRAVAIL [C. TRAV.] art. L. 1153-1 («Les agissements de harcèlement de toute personne dans le but d'obtenir des faveurs de nature sexuelle à son profit ou au profit d'un tiers sont interdits. »).

31. See Conseil constitutionnel [CC] [Constitutional Court], Commentaire, decision No. 2012-240 QPC, May 4, 2012, 2, available at http://www.conseil-constitutionnel.fr/conseilconstitutionnel/root/bank/download/2012240QPCccc_240qpc.pdf (discussing provisions on moral harassment in the Penal Code and the Labor Code, discussed in infra text accompanying notes 88103). 
obtain sexual acts from another person.

Cases applying this version of the provisions on sexual harassment indicate that establishing a claim of sexual harassment required a showing that the harasser actually was seeking to obtain sexual acts by his or her conduct. The criminal division of the Court of Cassation rejected the appeal of a convicted harasser that the claim against him had not been established because he did not have any actual intent to obtain sexual acts by his advances to a subordinate employee but was only joking, finding his appeal to be merely an attack on the fact-finding of the lower court. ${ }^{32}$ The court, however, seemed to confirm that such an intent was in fact required as an element of the offense. ${ }^{33}$

The requirement of intent to obtain sexual acts, however, was not interpreted as a requirement that the harasser be seeking to actually obtain the act of sexual intercourse. ${ }^{34}$ The criminal division of the Court of Cassation in another case rejected the appeal of a convicted harasser who made numerous sexual advances against a subordinate employee, including asking for kisses and trying to kiss her, putting his hands under her sweater and on her buttocks, and talking about sex in an obscene and vulgar manner, but argued that he could not have been seeking sexual acts because he suffered from erectile problems that made intercourse impossible; the lower court had indicated that the harasser's sexual problems were not relevant to whether his sexual advances constituted an intent to obtain sexual acts. ${ }^{35}$ Similarly, the Court of Appeals of Paris, applying the prohibition of sexual harassment, interpreted the term "favors of a sexual nature" broadly to mean "all acts of a sexual nature, and particularly simple physical touching intended to fulfill a sexual fantasy or to accentuate or to cause sexual desire." 36

With respect to the issue of coercion, it appears that the courts still required that the acts committed to obtain sexual acts be accomplished by means of some type of coercion, or at least by taking advantage of the vulnerability of employees. For example, in a case involving a male employee who directed repeated sexual acts at several female employees, including making sexual

32. Cour de cassation [Cass.] [supreme court for judicial matters] crim., Jan. 31, 2012, No. 1182.985, available http:/ / www.legifrance.gouv.fr/affichJuriJudi.do?oldAction=rechJuriJudi\&idTexte=JURITEXT000025 470967\&fastReqId=1778231722\&fastPos=1. See also Cour de cassation [Cass.] [supreme court for judicial matters] crim., Nov. 10, 2004, Bull. crim. No. 280, p. 1056, No. 03-87.986, available at http:/ / www.legifrance.gouv.fr/affichJuriJudi.do?oldAction=rechJuriJudi\&idTexte=JURITEXT000007 069892\&fastReqId=1633055263\&fastPos $=1$.

33. Id. See also Cour de cassation [Cass.] [supreme court for judicial matters] crim., Nov. 10, 2004, No. 03-87.986 (reversing decision of court of appeals, which had found a teacher guilty of sexual harassment for telling a 14-year-old student that he loved her and kissing her three times on the mouth, because the court of appeals did not explain how his behavior constituted aggressive behavior with the goal of obtaining sexual acts from the student).

34. See Cour de cassation [Cass.] [supreme court for judicial matters] crim., Sept. 30, 2009, No. 09-80.971, available at http://www.legifrance.gouv.fr/affichJuriJudi.do?oldAction=rech JuriJudi\&idTexte=JURITEXT000021194011\&fastReqId=744822691\&fastPos $=1$.

35. $I d$.

36. Cour d'Appel [CA] [regional court of appeal], Paris, 18 e ch., Jan. 18, 1996,, reported in Michel Miné, Le harcèlement sexuel, Droit Ouvrier, p 76-77 (Fevrier 1997). In French:« tout acte de nature sexuelle, et notamment les simples contacts physiques destinés à assouvir un phantasme d'ordre sexuel, voire à accenteur ou provoquer le désir sexuel ». 
advances, putting his hand on the thigh of one co-worker and trying to kiss her in the elevator, and placing his head between the thighs of another co-worker while she was sitting at a table and holding her down on a table while he placed whipped cream on her stomach and then licked it off, the court of appeals rejected his contention that his acts constituted simple workplace banter. In concluding that this conduct constituted sexual harassment, the court of appeals relied on the fact that the harasser took advantage of the targets of his harassment, who were experiencing distress because of difficult family situations. The criminal division of the Court of Cassation upheld the decision of the court of appeals. ${ }^{37}$ Similarly, although in a case not involving employment, the criminal division of the Court of Cassation reversed a decision of the court of appeals that had found a teacher guilty of sexual harassment for telling a 14year-old student that he loved her and kissing her on the mouth three times, because the court of appeals had not explained how his conduct constituted aggressive action seeking sexual conduct. ${ }^{38}$

The expansion of the penal provision on sexual harassment in connection with the Social Modernization Act was intended to allow the provision to be applied to a broader range of sexually harassing behavior, but that action ultimately doomed the provision, for this section of the Penal Code was held unconstitutional on May 4, 2012, by the French Constitutional Council (the Conseil Constitutionnel) as insufficiently precise for failing to define the elements that constituted the crime. ${ }^{39}$ The Constitutional Council held that the provision violated the principle that punishment could not be imposed if criminal offenses were not defined in terms sufficiently clear and precise; the provision therefore violated both Article 24 of the Constitution and Article 8 of the Declaration of the Rights of Man and the Citizen of August 26, 1789.40 Accordingly, the Council declared that the penal provision on sexual harassment was repealed effective with the publication of the decision in the Official Journal of the French Republic (Journal Officiel de la République Française) and that the repeal was effective as to all proceedings that had not been definitively resolved as of that date. ${ }^{41}$

The decision of the Constitutional Council addressed only the constitutionality of the Penal Code provision on sexual harassment, because that was the issue raised in the application for the priority preliminary ruling on an issue of constitutionality (question prioritaire de constitutionnalite or QPC) that was before it. However, the effect of that ruling on the validity of the Labor Code provisions on sexual harassment seems to have been the subject of some debate. The Commentary issued by the Secretary General of the Constitutional Council

37. Cour de cassation [Cass.] [supreme court for judicial matters] crim., May 11, 2010, No. 0984.011, available at http://www.legifrance.gouv.fr/affichJuriJudi.do?oldAction=rech JuriJudi\&idTexte=JURITEXT000021194011\&fastReqId $=744822691 \&$ fastPos $=1$.

38. Cour de cassation [Cass.] [supreme court for judicial matters] crim., Nov. 10, 2004, Bull. crim. No. 280, p. 1056, No. 03-87.986, available at http://www.legifrance.gouv.fr/affichJuriJudi.do ?oldAction=rechJuriJudi\&idTexte=JURITEXT000007069892\&fastReqId=1633055263\&fastPos=1.

39. Conseil constitutionnel [CC] [Constitutional Court] decision No. 2012-240 QPC, May 4, 2012, J.O.du 5 mai 2012, p. 8015.

40. Id.

41. Id. 
suggested that the ruling also called into question the validity of the similar Labor Code provisions, indicating that "[i]f their provisions are not contested, they are necessarily linked to the fate of the QPC because their content is close to that of the contested provision." 42 On the other hand, a circular issued by the Ministry of Justice emphasized that the decision of the Constitutional Council did not affect the non-penal aspects of the sexual harassment provisions of the Labor Code, which it indicated remained in effect:

It is appropriate to emphasize, on the other hand, that the decision of the Constitutional Council raises no objection to the non-penal aspects of the issue... the principle of the ban on harassment, the prohibition of dismissal of one who refuses harassment or who testifies, breach of discipline [by the harasser], the obligation of supervision by the employer ... provided by articles L. 1153-1 to L. 1153-6 and L. 1154-1 of the Labor Code. ${ }^{43}$

The reenactment of a sexual harassment law, after repeal of the previous provision, was viewed as a matter of some urgency, both because of the vacuum created by the absence of a criminal penalty for sexually harassing conduct and because of the possible implications of that decision on the law of the workplace more generally. ${ }^{44}$ Barely three months after the repeal, new provisions on sexual harassment were enacted into both the Penal Code and the Labor Code, ${ }^{45}$ with the unanimous approval of both the Senate and the National Assembly. ${ }^{46}$ Those

42. Conseil constitutionnel [CC] [Constitutional Court], Commentaire, decision No. 2012-240 QPC, May 4, 2012, 3, available at http:/ / www.conseil-constitutionnel.fr/conseilconstitutionnel/root/bank/download/2012240QPCccc_240qpc.pdf. In the original French : «Si ces dispositions ne sont pas contestées, elles sont nécessairement liées au sort de la QPC puisque leur contenu est proche de celui de la disposition contestée. ».

43. Circular of Ministère de la Justice et des Libertés, CRIM-AP No. 10-780-D2 (May 10, 2012), p. 4, http://www.avft.org/IMG/pdf/Circulaire_10-05-2012_-_harcelement_sexuel-2.pdf.. In the original French : «Il convient en revanche de souligner que la décision du Conseil constitutionnel n'a aucune incidence sur l'aspect non pénal de la question (principe de la prohibition du harcèlement, interdiction de licencier celui qui refuse du harcèlement ou qui témoigne, faute disciplinaire, obligation de surveillance de l'employeur ... prévus par les articles L. 1153-1 à L. 1153-6 et L. 1154-1 du code du travail. "See also Christophe Radé, Abrogation du délit de harcèlement sexuel: quelles conséquences en droit du travail ?, 21 RECUEIL DALLOZ 1392 (2012) (expressing the opinion that the regime of sexual harassment in the Labor Code is more complete than the Penal Code provision and that the decision of the Constitutional Council should not be able to abrogate Article L 1153-1 of the Labor Code, which defines sexual harassment, but only the penalty provision of that Code, Art. L 1155-2).

44. Loïc Lerouge, Actualités, Harcèlement : nouvelle dispositions issues de la loi du 6 août 2012, Droit Social, N 10 (Octobre 2012).

45. The new law was not retroactive, but became effective on August 7, 2012, with its publication in the Journal Officiel, and applies to actions that are committed as of August 8, 2012. Circular of Ministère de la Justice, CRIM No. 2012-15/E8, Présentation des dispositions de droit pénal et de procédure pénale de la loi $n^{\circ} 2012-954$ du 6 août 2012 relative au harcèlement sexuel (Aug. 7, 2012), http://www.textes.justice.gouv.fr/art_pix/1_1_circulaire_07082012.pdf.

46. Communiqué de presse de Christiane Taubira, garde des sceaux, ministre de la Justice [Press release of Christiane Taubira, Keeper of the Seals, Minister of Justice], " Harcèlement sexuel : adoption définitive de la nouvelle loi » [English translation] (July 31, 2012), http:/ / www.presse.justice.gouv.fr/archives-communiques-10095/archives-des-communiques-de2012-12363/harcelement-sexuel-adoption-definitive-de-la-nouvelle-loi-24473.html (noting that both the French Senate and National Assembly adopted the law relating to sexual harassment with unanimity and expressing the opinion that the unanimous vote by Parliament sends a strong message 
provisions contain a two-part definition of sexual harassment. The first part of the Penal Code provision indicates that:

Sexual harassment is the fact of imposing on a person, in a repeated manner, words or behavior with a sexual connotation, which undermine his or her dignity by reason of their degrading or humiliating nature or create against him or her an intimidating, hostile or offensive situation. ${ }^{47}$

The second part of the definition in the Penal Code provides that incorporated into the definition of sexual harassment is "the fact, even if not repeated, of using any form of serious pressure with the real or apparent goal of obtaining an act of a sexual nature, if it is sought for the benefit of the actor or the benefit of a third party." 48

The Labor Code provisions are similar, incorporating the same two parts of the definition of sexual harassment from those Penal Code provisions. The Labor Code provisions on sexual harassment provide that:

No employee shall be required to submit to facts

1. of sexual harassment, consisting of repeated words or behavior with a sexual connotation, which undermine his or her dignity by reason of their degrading or humiliating nature or create against him or her an intimidating, hostile or offensive situation;

2. incorporated into sexual harassment, consisting of any form of serious pressure, even if not repeated, exerted with the real or apparent goal of obtaining an act of a sexual nature, if it is sought for the benefit of the actor or the benefit of

about the fight against sexual harassment).

47. Loi 2012-954 du 6 août 2012 relative au harcèlement sexuel [Law 2012-954 of August 6, 2012, concerning sexual harassment], JOURNAL OFFICIEL DE LA REPUBLIQUE FRANÇAISE [J.O.] [OFFICIAL Gazette of France], Aug. 7, 2012, p. 12021; CODE PÉNAL [C. PÉN.] art. 222-33(I). In the original French : «Le harcèlement sexuel est le fait d'imposer à une personne, de façon répétée, des propos ou comportements à connotation sexuelle qui soit portent atteinte à sa dignité en raison de leur caractère dégradant ou humiliant, soit créent à son encontre une situation intimidante, hostile ou offensante. »

48. Loi 2012-954 du 6 août 2012 relative au harcèlement sexuel [Law 2012-954 of August 6, 2012, concerning sexual harassment], JOURNAL OFFICIEL DE LA REPUBLIQUE FRANÇAISE [J.O.] [OFFICIAL Gazette of France], Aug. 7, 2012, p. 12021; Code PenAl [C. Pen.] art. 222-33-2. In the original French: "Est assimilé au harcèlement sexuel le fait, même non répété, d'user de toute forme de pression grave dans le but réel ou apparent d'obtenir un acte de nature sexuelle, que celui-ci soit recherché au profit de l'auteur des faits ou au profit d'un tiers. » The use of the phrase « est assimilé au harcélement sexuel " ("is incorporated into sexual harassment" or "is considered to be sexual harassment") for this portion of the definition was intended to address concerns expressed that the definition of the French word " harcélement » connotes repetition, such that a single act could not constitute harassment; use of this phrase allows a single act of harassment to be actionable, if the requirements of the statute are met, while still respecting the dictionary definition of the term).

The reenactment of the sexual harassment provisions into the Penal Code also provided for an increase in penalties for violation of either part, to a term of imprisonment of two years and a fine of 30,000 euros, with enhanced penalties of three year's imprisonment and a fine of 45,000 euros for sexual harassment involving certain aggravating circumstances, such as harassment by a person abusing the authority of his or her position, harassment of a minor under 15 years of age, abuse of persons who are particularly vulnerable because of a number of personal or economic situations, if that vulnerability is known or apparent to the harasser, and harassment accomplished by several persons acting together. CODE PENAL [C. PEN.] art. 222-33(III). 
a third party. ${ }^{49}$

The Labor Code also includes other provisions relating to sexual harassment. For example, the Labor Code provides that employees may not be discriminated against or be subjected to adverse action in connection with employment decisions because the individual submitted to or refused to submit to harassing conduct, even if the harassing conduct did not consist of repeated actions, ${ }^{50}$ employees also may not be discriminated against or subject to adverse employment action for having testified about or having reported acts of sexual harassment. ${ }^{51}$ Another provision of the Code imposes an obligation on employers to "take all necessary actions with a view of preventing acts of sexual harassment." 52

The new provisions of the Penal and Labor Codes on sexual harassment retain the notion from the original version of the law to define as sexual harassment acts aimed at obtaining sexual acts, although this version makes clear that some use of coercion is required for actionable harassment, in the form of

49. CODE DU TRAVAIL [C. TRAV.] art. L. 1153-1. In the original French : « Aucun salarié ne doit subir des faits:

$1^{\circ}$ Soit de harcèlement sexuel, constitué par des propos ou comportements à connotation sexuelle répétés qui soit portent atteinte à sa dignité en raison de leur caractère dégradant ou humiliant, soit créent à son encontre une situation intimidante, hostile ou offensante ;

$2^{\circ}$ Soit assimilés au harcèlement sexuel, consistant en toute forme de pression grave, même non répétée, exercée dans le but réel ou apparent d'obtenir un acte de nature sexuelle, que celui-ci soit recherché au profit de l'auteur des faits ou au profit d'un tiers. »

50. CODE DU TRAVAIL [C. TRAV.] art. L. 1153-2 ("No employee... may be sanctioned, dismissed, or be subjected to discrimination, directly or indirectly (intentionally or unintentionally)... for having submitted or having refused to submit to facts of sexual harassment as defined in Art. L. 11531 , including, in the case mentioned in section 1 of that article, if the words or behavior have not been repeated."). In the original French : "Aucun salarié... ne peut être sanctionné, licencié ou faire l'objet d'une mesure discriminatoire, directe ou indirecte ... pour avoir subi ou refusé de subir des faits de harcèlement sexuel tels que définis à l'article L.1153-1, y compris, dans le cas mentionné au $1^{\circ}$ du même article, si les propos ou comportements n'ont pas été répétés. » The Labor Code provides that violations of this provision are punishable by one year's imprisonment and a fine of 3,750 euros. CODE DU TRAVAIL [C. TRAV.] art. L. 1155-2.

A corresponding provision was inserted into the Penal Code by the law reenacting the sexual harassment provision. That provision, contained in Article 225-1-1 of the Penal Code, provides that: "Discrimination consists of any distinctions made between persons because they have submitted or refused to submit to facts of sexual harassment as defined in Art. 222-33 or testified of those facts, including, in the case mentioned in section I of that article, if the words or behavior have not been repeated." In the original French: "Constitue une discrimination toute distinction opérée entre les personnes parce qu'elles ont subi ou refusé de subir des faits de harcèlement sexuel tels que définis à l'article 222-33 ou témoigné de tels faits, y compris, dans le cas mentionné au I du même article, si les propos ou comportements n'ont pas été répétés. » CODE PÉNAL [C. PÉN.] art. 225-1-1. The penalty for violation of this provision is three year's imprisonment and a fine of 45,000 euros, when the discrimination consists of the refusal to hire, the sanctioning, or the dismissal of an individual. CODE PÉNAL [C. PÉN.] art. 225-2.

51. CODE DU TRAVAIL [C. TRAV.] art. L. 1153-3 (“No employee may be sanctioned, dismissed, or subjected to discrimination for having testified of facts of sexual harassment or having reported them."). In the original French : "Aucun salarié ne peut être sanctionné, licencié ou faire l'objet d'une mesure discriminatoire pour avoir témoigné des agissements de harcèlement sexuel ou pour les avoir relatés. »

52. CODE DU TRAVAIL [C. TRAV.] art. L. 1153-5. In the original French: «L'employeur prend toutes dispositions nécessaires en vue de prévenir les faits de harcèlement sexuel. » 
any type of "serious pressure." 53 The new law also makes clear that harassment occurs whether the harasser is motivated by an actual aim to obtain sexual acts or only appears to be seeking that goal and whether he or she seeks those acts for his or her own benefit or for the benefit of another. And this provision definitively resolves the question left open by the prior versions of the prohibition on sexual harassment: even a single act of serious pressure, when the aim of that pressure is to obtain sexual acts, is expressly stated to be sufficient to constitute a legal claim of sexual harassment. Accordingly, regardless of the dictionary definition of the French verb «harceler» (to harass), the legal definition of the term "sexual harassment" need not necessarily consist of repeated acts, when that harassment has the aim of obtaining sexual acts.

But the new provisions also introduce a new conception of sexual harassment into the provisions of the Labor and Penal Codes, that of the use of repeated words or actions with a sexual connotation to impair one's dignity, through degrading or humiliating conduct, or to create an intimidating, hostile, or offensive situation for the harassed individual. For this type of sexual harassment, repetition of acts is expressly required. There is no requirement that the sexually related acts be motivated by an intent to obtain sexual acts from the target of harassment or, indeed, any express requirement that the acts be motivated by any intent at all. Instead, the provision focuses on conduct that harms the dignity of the target of harassment or subjects him or her to a hostile, intimidating, or offensive situation. There is also no express requirement of coercion, in the form of serious pressure or otherwise, in this part of the definition in either the Penal or Labor Code provisions, although the use of the term "imposing" in the Penal Code, 54 as well as the prohibition on requiring an

53. The nature of sexual harassment set forth in this portion of the definition has been described as a form of "sexual blackmail" (in French, « chantage sexuel »). See Sénat, Session Extraordinaire de 2011-2012, Séance du mercredi 11 juillet 2012, Compte rendu intégral, , JOURNAL OFFICIEL DE LA REPUbLIQUE FRANÇAIS [J.O.] [OFFICIAL GAZETTE OF FRANCE], July 12, 2012, p. 2009 (statement of Mme Christiane Taubira, garde de sceaux, ministre de la justice, introducing project of law on new sexual harassment provisions); Assemblée Nationale, Session Extraordinaire de 2011-2012, Séances du mardi 24 juillet 2012, Compte rendu intégral, JOURNAL OFFICIEL DE LA REPUBLIQUE FRANÇAIS [J.O.] [OFFICIAL GAZETTE OF FRANCE], July 25, 2012, p. 2367 (statement of Mme Pascale Crozon, rapporteure de la commission des lois constitutionnelles, discussing « chantage sexuel »).

54. See Sénat, Session Ordinaire de 2011-2012, Rapport d'Information No. 596, fait au nom de la commission des affaires sociales (1), de la commission des lois constitutionnelles, de législation, du suffrage universel, du Règlement et d'administration générale (2) et de la délégation aux droits des femmes et à l'égalité des chances entre les hommes et les femmes (3), par le groupe de travail sur le harcèlement sexuel (4), June 15, 2012, p. 46 (statement of Mme Maryvonne Caillibotte, directrice des affaires criminelles et des grâces, ministère de la justice, explaining that the non-acceptance of the victim was an element of the proposed definition of sexual harassment, as reflected in the use of term "behavior imposed" / in French "comportements imposés »); id. at 112 (statement of Mme MarieThérèse Bruguière, expressing the view that use of the term "imposed" was preferable to use of the term "non-consensual" to refer to the acts constituting harassment, because that would not require the victim to establish that she had refused the acts).

See also Sénat, Session Extraordinaire de 2011-2012, Séance du mercredi 11 juillet 2012, Compte rendu intégral, JOURNAL OFFICIEL DE LA REPUBLIQUE FRANÇAIs [J.O.] [OFFICIAL GAZETTE OF FRANCE], July 12, 2012, p. 2009 (statement of Mme Christiane Taubira, garde de sceaux, ministre de la justice, introducing project of law on new sexual harassment provisions and explaining that use of word « imposer " (to impose) was intended to mean that the victim did not consent to or desire the acts of harassment but submitted to them, but that there is no requirement that the victim show that she 
employee to submit to harassment in the Labor Code, presumably suggest that the words or behavior being inflicted on the target of harassment are unwanted. The same reading is presumably suggested by the notion that the words and behavior undermine dignity because of their "degrading and humiliating" nature, because it is difficult to imagine that the legislators thought that degrading and humiliating conduct would be inflicted with the consent of the employee.

The conception of harassment reflected in this new definition, however, is not so much new as borrowed from the definition of sexual harassment found in the European Union directives on discrimination, which were required to be incorporated into French law on discriminatory harassment; those directives, as discussed below, ${ }^{55}$ also make use of the concepts of violation of dignity and creation of a hostile or offensive environment. ${ }^{56}$

One might reasonably wonder whether, by apparently borrowing the language concerning violation of dignity and creation of a hostile or offensive environment from the Labor Code provision on discriminatory harassment and, in turn, from the European Union directives on discrimination on which this Labor Code provision is based, this current articulation of sexual harassment also intended to borrow the underlying theoretical underpinning of those provisions, that is, the concept of discrimination as a motivating factor for the harassment. But other factors suggest that that is in fact not the case.

In general, French law appears to view the concepts of harassment and discrimination as analytically distinct, as reflected in the separation of those concepts in different parts of the Penal and Labor Codes. The history behind the original adaptation of the sexual harassment provisions in the Penal Code demonstrates that this separation of the provisions on harassment and discrimination in different parts of the Codes was not accidental. As originally proposed, the provision that became the prohibition against sexual harassment was located in the portion of the Penal Code on discrimination and did not use the term "harassment." 57 An amendment in the Senate added a reference in the provision to the term "harassment," and the National Assembly moved the provision out of the portion of the Code on discrimination and into the portion on crimes of sexual aggression. ${ }^{58}$

In addition, there was a good deal of opposition to defining harassment as a form of discrimination under French law at all, as reflected in the fact that the national government failed to do so until after the issuance of two warnings and a reasoned opinion from the European Commission to France for failure to

expressed disapproval of the acts in a direct manner).

55. See infra text accompanying notes 105 to 114 .

56. Although the word "situation" rather than "environment" was used in the enacted version of the new sexual harassment provisions, the language initially proposed by the government in the Project of Law introduced into the Senate was "environment," which was changed to "situation" during consideration by the Senate. For a discussion of the likely reason for and effect of this change, see infra text accompanying notes 81 to 82 .

57. Sénat, Première Session Ordinaire de 1991-1992, Séance du jeudi 3 octobre 1991, Débats

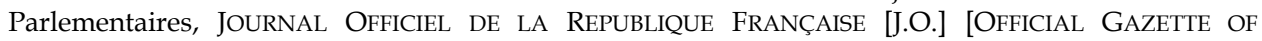
FRANCE], Oct. 3, 1991, p. 2627-28.

58. See Dekeuwer-Defossez, supra note 23. 
correctly transpose European Directives on discrimination into French national law. ${ }^{59}$ This failure was in part motivated by the existence of different conceptions of harassment under European Union law and French national law. That is, while French national law did not consider harassment to be a form of discrimination, for the European Commission, harassment, or at least sexual harassment, was inherently discriminatory in nature. ${ }^{60}$ One of the failures of transposition for which France was cited was the fact that harassment was not defined as a form of discrimination. ${ }^{61}$

That this difference of opinion about the conceptual basis for and the theoretical underpinnings of a claim of sexual harassment has not been completely resolved seems to be reflected in the fact that French national law did not replace its preexisting prohibition of sexual harassment with the one mandated by the European Union, but simply added what was required by the European Commission as an additional claim of discriminatory harassment. ${ }^{62}$ In fact, although the definition provided by the law transposing the directive into national law clearly seems to be describing a claim of harassment, the term "harassment" is not used in the law. ${ }^{63}$ This continuing tension between competing conceptions of sexual harassment makes it very unlikely that the French legislators intended to silently incorporate any conception or requirement of a discriminatory motive into its "own" version of a sexual harassment claim.

The express provisions of the new statute do not contain any requirement that actionable sexual harassment be based on any discriminatory motive. The definition of sexual harassment contained in that new statute references dignity and the creation of a hostile situation, as well as the concept of coercion of sexual acts, but not discriminatory motive. In fact, as discussed below, even the provision of the Labor Code defining discriminatory sexual harassment does not expressly require a showing of a discriminatory motive, as long as the harassment has a sexual connotation. ${ }^{64}$

59. See Marie-Thérèse Lanquetin, Discriminations: le loi d'adaption au droit communautaire du 27 mai 2008, DROIT SOCIAL, Juillet-Août 2008, n 7/8, at 778. See also Memorandum on "'Employment Directive (2000/78/EC)" from the European Union, No. 08/68 (Jan. 31, 2008), http://europa.eu/rapid/press-release_MEMO-08-68_en.htm (list of Member States to which a reasoned opinion or letter of formal notice will be sent, including France, listed under reasoned opinion for "[i]ncorrect definitions of direct and indirect discrimination and harassment").

60. Lanquetin, supra note 59 , at 781.

61. Sénat, Session Ordinaire de 2007-2008, Rapport d'information No. 252 de Mme Christiane Hummel, Sénateur, Apr. 1, 2008, p. 11 (discussing the differences between France's definition of harassment and the European Union's preferred definition of harassment). Other failures with respect to France's definition of sexual harassment was that that definition required repeated actions, while the European Directive's definition did not, and that the notion of degradation of workplace conditions was narrower than the notion of an intimidating environment. $I d$.

62. Michel Miné, Discriminations: une transposition laborieuse ..., Libertés et pouvoirs, Revue de Droit du Travail, Septembre 2008, p. 532, 533-34 (discussing the potential problems created by the fact that the different provisions on harassment were maintained in the Labor and Penal Codes).

63. Id. at 533 (noting the fact that the law recognizing certain forms of harassment as a form of discrimination "curiously does not use the term of harassment"). In the original French: "Grâce au droit communautaire, la loi permet enfin de reconnâitre certains harcèlements comme des discriminations, sur le terrain civil, même si la loi n'emploie pas, curieusement, le terme de harcèlement. »

64. See infra text following note 114 . 
In addition, the explanation of the statute in the circular issued by the Ministry of Justice 65 does not reference any requirement that a claim of sexual harassment be based on any discriminatory motive. That document mentions discrimination in two different contexts. First, with respect to sexual harassment, the document addresses discrimination against a person who has been subjected to sexual harassment, ${ }^{66}$ which, as discussed above, is also prohibited under the new sexual harassment provisions. ${ }^{67}$ Second, that document discusses, in a separate section, a clarification in the law that makes explicit that discrimination on the basis of gender identity is prohibited by the anti-discrimination provisions of the Labor and Penal Codes. ${ }^{6}$ Tellingly, the provisions on discrimination because of sexual harassment are codified with the Code provisions on sexual harassment, while the provisions on discrimination because of gender identity are codified in the section of the Code that also prohibits discriminatory harassment. This separation further demonstrates that the prohibition on sexual harassment under French law is separate from, and not based upon, any notion of discriminatory motivation. ${ }^{69}$

The preliminary documents (les travaux préparatoires) of the new statute also seem to confirm this separation between the notions of harassment and discrimination. For example, the Impact Study of the Project of Law issued by the Ministry of Justice with respect to the new sexual harassment provisions indicate that one of the objectives of the new law was to "reestablish coherence between the Penal Code and the Labor Code and to distinguish clearly the question of the definition and penalization of sexual harassment from that of the definition and penalization of discrimination."70 The discrimination of which the study speaks appears to be discrimination against the victims of sexual harassment, but this language still suggests the desire to draw a clear distinction between sexual harassment and discrimination. The study also makes clear the

65. Circular of Ministère de la Justice, CRIM No. 2012-15/E8, supra note 45.

66. Id. at 9-12 (discussing provision of new statute providing a penalty for discrimination against a person who is subject to discrimination resulting from acts of sexual harassment).

67. See supra text accompanying note 50.

68. Circular of Ministère de la Justice, CRIM N²012-15/E8, supra note 45, at 12-13 (discussing provision of new statute providing a penalty for discrimination against a person who is subject to discrimination resulting from acts of sexual harassment).

69. The provision on gender identity was originally proposed to be added to the new sexual harassment statute as an aggravating factor for sexual harassment, so that harassment motivated by one's gender identity would be punishable by increased penalties. See Sénat, Session Extraordinaire de 2011-2012, Séance du mercredi 11 juillet 2012, Compte rendu intégral, JOURNAL OfFICIEL DE LA RepubliQue Français [J.O.] [OFFICIAL GAZETTE OF FRANCE], July 12, 2012, p.2062-65 (discussing sexual orientation and identity in relation to the vulnerability of the victim and gender identity's status as an aggravating factor). That amendment was withdrawn and a new amendment was proposed, which would add gender identity to the anti-discrimination provisions of the Penal Code and the Labor Code; that amendment was adopted. Sénat, Session Extraordinaire de 2011-2012, Séance du jeudi 12 juillet 2012, Compte rendu intégral, JOURNAL OFFICIEL DE LA REPUBLIQUE FRANÇAIS [J.O.] [OFFICIAL GAZETTE OF FRANCE], July 13, 2012, p. 2125-29.

70. Etude d'impact pour le projet de loi relatif au harcèlement sexuel [Impact Study for the project of law related to sexual harassment] 31 (June 2012). In the original French : " rétablir la cohérence entre le code pénal et le code du travail et distinguer clairement la question de la définition et de la pénalisation du harcèlement sexuel de celle de la définition et de la pénalisation des discriminations ». 
government's position, in explaining why consultation with the Supreme Council for Professional Equality Between Woman and Men (le conseil supérieur de l'égalité professionnelle entre les femmes et les hommes) was not mandatory with respect to the draft sexual harassment law, that sexual harassment is not discriminatory because, even though it generally affects women more than men, it can exist without regard to the sex of the victim or the perpetrator. ${ }^{71}$

Interestingly, however, in spite of the general view among those involved in the enactment of the new sexual harassment provisions that sexual harassment is not a form of discrimination, several participants in the process expressed the view that the existence of sexual harassment within French society and in its workplaces does implicate issues of equality between men and women. For example, in discussing the newly introduced project of law relating to sexual harassment, Madame Najat Vallaud-Belkacem, the minister of women's rights and the government's spokesperson, stated: "Indeed, the issue of sexual harassment is serious; without visible signs that it is considered to be intolerable, we do not build a society of justice, of respect, and of equality between women and men."72 Even more strongly, she asserted the government's view that "sexual harassment is a manifestation of a society based on inequality between women and men."73

71. Id. at 38-39. A similar desire to draw a clear distinction between sexual harassment and discrimination is found in the report of the working group created by the Senate in connection with the consideration of the new sexual harassment provisions, in which the need was expressed to distinguish between harassment based on gender, seen as a form of discrimination, and sexual harassment, which consisted of sexual acts. Sénat, Session Ordinaire de 2011-2012, Rapport d'Information No. 596, fait au nom de la commission des affaires sociales (1), de la commission des lois constitutionnelles, de législation, du suffrage universel, du Règlement et d'administration générale (2) et de la délégation aux droits des femmes et à l'égalité des chances entre les hommes et les femmes (3), par le groupe de travail sur le harcèlement sexuel (4), June 15, 2012, p. 88 (statement of Mme Brigitte Gonthier-Maurin, présidente de la Délégation aux droits des femmes).

72. Sénat, Session Extraordinaire de 2011-2012, Séance du mercredi 11 juillet 2012, Compte rendu intégral, JOURNAL OFFICIEL DE LA REPUBLIQUE FRANÇAIS [J.O.] [OFFICIAL GAZETTE OF FRANCE], July 12, 2012, p. 2013 (In the original French, «En effet, la question du harcèlement sexuel est grave : sans signaux visibles qu'il est considéré comme intolérable, on ne construit pas une société de justice, de respect et d'égalité entre les femmes et les hommes. "). Similarly, when Madame Najat VallaudBelkacem spoke in favor of the proposed legislation to the National Assembly, she indicated that acts of sexual harassment are intolerable, not only because of the suffering that they imposed on the victims but that they are intolerable for the entire society to be founded on justice, respect, and equality between men and women. Assemblée Nationale, Session Extraordinaire de 2011-2012, Séances du mardi 24 juillet 2012, Compte rendu intégrale, JOURNAL OFFICIEL DE LA REPUBLIQUE FRANÇAIS [J.O.] [OFFICIAL GAZETTE OF FRANCE], July 25, 2012, p. 2365 (In French, « Ces actes sont intolérables. Ils le sont pour eux-mêmes, pour les souffrances imposées aux victimes, mais ils le sont aussi pour la société tout entière, la société que nous voulons fondée sur la justice, sur le respect et sur l'égalité entre les femmes et les hommes. »).

73. Sénat, Session Extraordinaire de 2011-2012, Séance du mercredi 11 juillet 2012, Compte rendu intégral, JOURNAL OFFICIEL DE LA REPUBLIQUE FRANÇAIS [J.O.] [OFFICIAL GAZETTE OF FRANCE], July 12, 2012, p. 2045 (statement of Madame Najet Vallaud-Belkacem) (In French, « Madame Meunier, vous aussi avez rappelé que le harcèlement sexuel est une manifestation d'une société fondée sur l'inégalité entre les femmes et les hommes. »). Similarly, in her statement to the National Assembly, Madame Pascale Crozon, rapporteure, indicated that inequality between men and women was a source of sexual harassment. Assemblée Nationale, Session Extraordinaire de 2011-2012, Séances du mardi 24 juillet 2012, Compte rendu intégral, JOURNAL OFFICIEL DE LA REPUBLIQUE FRANÇAIS [J.O.] [OFFICIAL GAZETTE OF FRANCE], July 25, 2012, p. 2367. 
A similar view was expressed by Madame Christiane Demontès, member of the Senate and reporter for the views of the Commission on Social Affairs with respect to the issue of sexual harassment: "[T]he question of sexual harassment has close ties with subjects that are at the heart of the concerns of the Commission on Social Affairs. I think of the quality of the life of work, the prevention of psychosocial risks, and the professional equality between men and women."74 And Madame Bariza Khiari, acting as president of the Senate on the consideration of the new sexual harassment provisions, expressed the view that: "The Constitutional Council, perhaps unwittingly, gave us the opportunity to improve the law and harden the repression of sexual harassment to advance equality between men and women."75 Perhaps the most strongly stated view of the connection between sexual harassment and equality or inequality was expressed by Madame Pascale Crozon, the reporter for the Commission on Constitutional Laws, who seemed to suggest that not only was sexual harassment caused by gender inequality but that there was a link between sexual harassment and sexism: "We must all be convinced that professional equality is the best prevention against sexual harassment and that the realization of equality ... occurs through the prevention of sexism."76

It should be noted that while the new provisions on sexual harassment borrow some concepts from the Labor Code provisions on discriminatory harassment and the European Union directives on discrimination, there are still important differences between the definitions of sexual harassment and discriminatory harassment. In particular, the definition of discriminatory harassment seems to focus solely on the purpose or effect of sexually harassing conduct, while the new provision on sexual harassment also seeks to define the

74. Sénat, Session Extraordinaire de 2011-2012, Séance du mercredi 11 juillet 2012, Compte rendu intégral, JOURNAL OFFICIEL DE LA REPUBLIQUE FRANÇAIS [J.O.] [OFFICIAL GAZETTE OF FRANCE], July 12, 2012, p. 2017 (In the original French, « Par conséquent, la question du harcèlement sexuel entretient des liens étroits avec des sujets qui sont au cœur des préoccupations de la commission des affaires sociales. Je pense à la qualité de la vie du travail, à la prévention des risques psychosociaux et à l'égalité professionnelle entre les hommes et les femmes. ").

But see id. at 2029 (statement of M. Jean-Jacques Hyest) (objecting to the introduction of allusions of gender into the debate because "the victims of sexual harassment have not been the object of discrimination; they are all equal, and must be protected equally." In French, «les victimes de harcèlement sexuel n'ont pas à faire l'objet de discrimination: elles sont toutes égales, et doivent être protégées également. »).

75. Sénat, Session Extraordinaire de 2011-2012, Séance du jeudi 12 juillet 2012, Compte rendu intégral, JOURNAL OFFICIEL DE LA REPUBLIQUE FRANÇAIs [J.O.] [OFFICIAL GAZETTE OF FRANCE], July 13, 2012, p. 2148 (In French, «Le Conseil constitutionnel, peut-être involontairement, nous a donné l'occasion de parfaire la loi et de durcir la répression du harcèlement sexuel pour faire progresser l'égalité entre les hommes et les femmes. »).

76. Assemblée Nationale, Session Extraordinaire de 2011-2012, Séances du mardi 24 juillet 2012, Compte rendu intégral, JOURNAL OFFICIEL DE LA REPUBLIQUE FRANÇAIS [J.O.] [OFFICIAL GAZETTE OF FRANCE], July 25, 2012, p. 2367 (statement of Mme Pascale Crozon, rapporteure de la commission des lois constitutionnelles [reporter of the commission on constitutional laws]) (In French, « Nous devons tous être convaincus que l'égalité professionnelle est la meilleure prévention contre le harcèlement sexuel et que la réalisation de l'égalité ... passe par la prévention du sexisme. »). See also id. at 2374 (statement of Mme Ségolène Neuville, rapporteure de la délégation aux droits des femmes et à l'égalité des chances entre les hommes et les femmes [reporter of the delegation of rights of women and equality of opportunities between men and women]) (suggesting relationship between sexism and sexual stereotypes and the existence of sexual harassment). 
nature of conduct that can lead to sexual harassment, by referencing the "degrading or humiliating nature" of that conduct. ${ }^{77}$ The Impact Study accompanying the Project of Law from the Ministry of Justice explained that this language was chosen to lessen the possibility that the new provision would be found insufficiently precise by the Constitutional Council; that study explains that the government believed that a focus on only the consequences of conduct would not allow criminalization of that conduct, while including requirements for the conduct itself would avoid any constitutional problems. ${ }^{78}$ It appears that the language in the new sexual harassment provisions requires a showing that the conduct claimed to constitute sexual harassment was in fact degrading or humiliating in nature, in addition to a showing that the conduct actually harmed dignity or created a hostile situation.

Differences in language between the two provisions also raise an issue as to whether a showing of intent is necessary to establish the existence of sexual harassment under this new provision. The use of the terms "purpose or effect" in the discriminatory harassment provisions would seem to indicate that no showing of intent is required, because either an intent or a consequence of harming dignity or creating a hostile environment would be sufficient. As explained below, ${ }^{79}$ that is the manner in which similar language in the moral harassment provisions of the Labor Code has been interpreted. The effect of the absence of this language from the new sexual harassment provisions in the Labor Code is unclear. Certainly there is no express requirement of intent in that provision, because by its terms, the new provision on sexual harassment merely prohibits actions that cause harm to dignity or create a hostile environment, suggesting that the focus is on the consequence of, and not the intent behind, harassing conduct. Alternatively, the deletion of the term "purpose" might have been intended to impose a requirement that the harmful effects on dignity and the work environment actually occur in order for actionable sexual harassment to be shown, rather than that the actions merely have the intent to bring about those effects. It is also possible that the deletion of the term "effect" might have been intended to suggest that sexual harassment cannot be established merely by the consequences of that conduct, but this would appear to be a strained interpretation of a statutory provision that contains no express requirement of

77. In the original French, the new sexual harassment provisions refer to acts with a sexual connotation «qui soit portent atteinte à sa dignité en raison de leur caractère dégradant ou humiliant» et «soit créent à son encontre une situation intimidante, hostile ou offensante ». CODE PENAL [C. PEN.] art. 222-33(I); CODE DU TRAVAIL [C. TRAV.] art. L. 1153-1, while the provisions on discriminatory harassment refer to acts with a sexual connotation « ayant pour objet ou pour effet une dégradation des conditions de travail susceptible de porter atteinte à ses droits et à sa dignité», Code Penal [C. PEN.] art. 222-33-2; Code DU TRAVAIL [C. TRAV.] art. L. 1152-1.

78. Etude d'impact pour le projet de loi relatif au harcèlement sexuel [Impact Study for the project of law related to sexual harassment] 32-34 (June 2012). Curiously, cited in support of this conclusion is the fact that the statutory provisions on moral harassment, which also focus on harm to dignity, have been held to be constitutional by the Constitutional Council; those provisions, however, as discussed below at infra text accompanying notes 88-103, focus only on the purpose or effect of harassing conduct, not its nature. It is difficult to understand how a focus on the purpose or effect of morally harassing behavior would be valid, while a similar focus on the purpose or effect of sexually harassing behavior would not.

79. See infra text accompanying notes 95 to 96. 
intent. 80

Another difference between the language of the new sexual harassment provisions and the provision on discriminatory harassment is the requirement that the conduct create "an intimidating, hostile or offensive situation" against the target of harassment for a sexual harassment claim, while the discriminatory harassment provisions require that the harassing conduct create an intimidating, hostile, degrading, humiliating, or offensive environment. Interestingly, the descriptors of "degrading" and "humiliating" are used in the sexual harassment provisions to define the nature of the conduct that must exist for actionable sexual harassment, rather than the consequences of that conduct. In addition, with respect to the consequences of that conduct, the sexual harassment provisions require the creation of an intimidating, hostile or offensive "situation" rather than an "environment." The addition of the words "à son encontre " (against him or her) also seem to indicate the requirement of a more direct effect of the harassment on the particular target of harassment.

An explanation for this difference in language is found in the report of the working group created by the Senate in connection with consideration of the new sexual harassment provisions, suggesting that the term "environment" might be too imprecise and indicating that the term "situation" might more objectively describe the particular climate suffered by a target of sexual harassment. ${ }^{81} \mathrm{~A}$ similar view was expressed during the debates on the new sexual harassment provisions, during consideration of an amendment to substitute the term "situation" for "environment." 82

Although sexual harassment has been prohibited in both the Labor Code and the Penal Code since 1992, most of the cases applying those provisions have involved decisions of the criminal courts, applying the Penal Code provision, rather than decisions of the labor courts, applying the Labor Code provisions. This is probably not surprising, given the original focus of the definition of sexual harassment on the abuse of authority and coercion and its apparent links with sexual violence and aggression. And given that the Court of Cassation

80. With respect to the sexual harassment provision of the Penal Code, a requirement of intent is likely to be read into the provisions of the statute, similar to what has happened with respect to the Penal Code provisions on moral harassment, on the ground that harassing conduct cannot be criminally penalized without a showing of deliberate action on the part of the perpetuator of harassment. See infra text accompanying note 96.

81. Sénat, Session Ordinaire de 2011-2012, Rapport d'Information No. 596, fait au nom de la commission des affaires sociales (1), de la commission des lois constitutionnelles, de législation, du suffrage universel, du Règlement et d'administration générale (2) et de la délégation aux droits des femmes et à l'égalité des chances entre les hommes et les femmes (3), par le groupe de travail sur le harcèlement sexuel (4), June 15, 2012, p. 10, 91-92.

82. See Sénat, Session Extraordinaire de 2011-2012, Séance du mercredi 11 juillet 2012, Compte rendu intégral, JOURNAL OFFICIEL DE LA REPUBLIQUE FRANÇAIS [J.O.] [OFFICIAL GAZETTE OF FRANCE], July 12, 2012, p. 2040 (statement of M. François Pillet) (in addition to suggesting that use of the word "situation" was more objective than the word «environnement, " he indicated that the word «environnement" was only a translation of the English word «environment»); id. at 2051-53 (discussion and adoption of amendment in Senate). See also Assemblée Nationale, Session Extraordinaire de 2011-2012, Séances du mardi 24 juillet 2012, Compte rendu intégral, JOURNAL OfFiciel De LA Republique FRANÇAis [J.O.] [OFFICIAL GAZETTE OF FRANCE], July 25, 2012, p. 2361(statement of Mme Christiane Taubira) (explaining why the legal commission preferred the term « situation » to « environnement »). 
followed a practice of conforming the law concerning sexual harassment under both codes, it is likely that the focus on the Penal Code provisions resulted in a more restrictive definition of sexual harassment than might have otherwise been the case. ${ }^{83}$ Indeed, one might suppose that this focus on the criminal aspects of sexual harassment is at least partially responsible for what has been generally viewed as the chronic underenforcement of sexual harassment law in France. ${ }^{84}$

While consideration of the new sexual harassment provisions was directly motivated by the decision of the Constitutional Council to invalidate the previous version of the statute, it appears that the government used that opportunity to expand and strengthen the definition of sexual harassment under French law, at least in part to address the sense that French law had not previously taken the issue of sexual harassment seriously. ${ }^{85}$ In doing so, it is

83. See Élisabeth Fortis, Harcèlement moral en droit pénal et en droit du travail, unité ou dualité?, 1482 SEMAINE SOCIALE LAMY 8 (2011) (noting that the Court of Cassation has opted for a unified interpretation of sexual harassment and that the action has admittedly posed an obstacle to providing remedies for sexual harassment in the context of employment); id. at 10 (discussing the links between the offense of sexual harassment and sexual aggression and suggesting that legislators may have conceived of sexual harassment as a milder form of sexual violence).

84. See Assemblée Nationale, Rapport No. 86 sur le projet de loi (No. 82), adopté par le Sénat après engagement de la procédure accélérée, relatif au harcèlement sexuel [Report No. 86 regarding the project of law adopted by the Senate related to sexual harassment], July 18, 2012, p. 13 (describing survey conducted in 2007 by department in Paris of sexual violence against women, indicating that $45 \%$ of the respondents indicated having heard sexist jokes at work, $14 \%$ reported being subjected to pornography at work, and $14 \%$ reported having received sexually aggressive verbal advances); $i d$. at 15 (data collected by prosecutors indicate that between 800 and 900 new cases of sexual harassment were brought each year between 2003 and 2008, but that between 2003 and 2010, there were only 70 to 85 offences each year resulting in condemnation); $i d$. at 22 (statistics provided by the Ministry of Justice indicate that although a penalty of imprisonment is pronounced in $78 \%$ of case of condemnations, the sentence is usually suspended, and in the 2 to 4 cases each year in which imprisonment is actually ordered, the average period of imprisonment is between 2 and 3.8 months).

See also Etude d'impact pour le projet de loi relatif au harcèlement sexuel [Impact Study for the project of law related to sexual harassment] 11-12 (June 2012) (reporting statistics concerning the very low number of cases in which the offense of discrimination against a victim of sexual harassment for reporting or refusing to submit to sexual harassment resulted in condemnation between 1994 and 2008); Assemblée Nationale, Session Extraordinaire de 2011-2012, Séances du mardi 24 juillet 2012, Compte rendu intégral, JOURNAL OFFICIEL DE LA RÉPUbliQue FRANÇAIS [J.O.] [OFFICIAL GAZETTE OF FRANCE], July 25, 2012, p. 2372 (statement of Mme Catherine Lemorton, présidente de la commission des affaires sociales [English translation]) (noting that in a country with a population of 63 million, there are on average 80 cases a year in which individuals are condemned for sexual harassment).

See also Sénat, Session Ordinaire de 2011-2012, Rapport d'Information No. 596, June 15, 2012, p. 31 (Mme Isabelle Steyer, avocate de la Fédération nationale "Solidarité femmes », noting that the former criminal offense of sexual harassment was little used, partly because it was not understood by the police, detectives, and judges); id. at 94 (statement of M. François Molins, procureur de la République, indicating that very few cases of sexual harassment result in condemnations, with only two such cases in Paris in 2010 and only one such case in 2011).

85. This intent is reflected in the discussions in the Senate and National Assembly of the new sexual harassment provisions. See Assemblée Nationale, Session Extraordinaire de 2011-2012, Séances du mardi 24 juillet 2012, Compte rendu intégral, JOURNAL OFFICIEL DE LA REPUBLIQUE FRANÇAISE [J.O.] [OFFICIAL GAZETTE OF FRANCE], July 25, 2012, p. 2367 (statement of Mme Pascale Crozon, rapporteure) (noting that language from the European directives was used in part because those guidelines cover a very wide spectrum of possible situations of sexual harassment); Sénat, Session Extraordinaire de 2011-2012, Séance de mardi 31 juillet 2012 Compte rendu intégral,, JOURNAL OfFiciel de la Republique Française [J.O.] [OFficial GAZETTE Of FranCE], Aug. 1, 2012, p. 2745 
possible that the new sexual harassment provisions, focusing not just on efforts to obtain sexual acts but also on degrading and humiliating conduct of a sexual nature that undermines dignity or creates a hostile environment, may reflect, or may result in, a fundamental change in the way that sexual harassment is viewed under French law. No longer linked only to sexual coercion, but instead also invoking dignitary harm and creation of hostile or intimidating situations, the broader definition of sexual harassment should be seen to be applicable to a broader range of conduct and circumstances and more linked, under the Labor Code, to injuries to the workplace environment. ${ }^{86}$ In addition, much of the discussion of sexual harassment by French legislators during consideration of the new sexual harassment provisions, while not establishing a claim based on discrimination, seemed to recognize and give credence to the ways in which sexual harassment implicates and is related to issues of gender equality. It will take some time, however, to determine how this new statute will be used by litigants and applied by the courts. ${ }^{87}$

\section{B. The Prohibitions of Moral Harassment}

In addition to the prohibitions of sexual harassment contained in the French Penal and Labor Codes, those codes also contain prohibitions of moral harassment. The provisions on moral harassment were enacted as part of the Social Modernization Act in 2002.88 The adoption of these provisions resulted from a national discussion of this phenomenon in France, following the 1998

(statement of Mme Christiane Demontès) (indicating the double objective of the text of the new sexual harassment provisions - to respond to the gap left by the decision of the Constitutional Council invalidating the law and to bring the definition of sexual harassment in French law closer to the approach of the European directives). See also Assemblée Nationale, Session Extraordinaire de 2011-2012, Séances du mardi 24 juillet 2012, Compte rendu intégral, JOURNAL OFFICIEL DE LA REPUBLIQUe FRANÇAISE [J.O.] [OFFICIAL GAZETTE OF FRANCE], July 25, 2012, p. 2382 (statement of Mme. Sonia Lagarde) (suggesting that the abrogation of the sexual harassment law by the Constitutional Council might be used to address the fact that sexual harassment has not always been addressed with the seriousness that is required).

86. There are indications in the discussions surrounding the enactment of the new sexual harassment provisions that the new definitions might lead to an understanding of sexual harassment under French law less focused on solely harm to the individual and more focused on the systemic harms caused to the workplace in general, similarly to the way that moral harassment is viewed, leading to an obligation on the part of the employer to prevent the risks associated with sexual harassment. Assemblée Nationale, Session Extraordinaire de 2011-2012, Séances du mardi 24 juillet 2012, Compte rendu intégrale, Journal OfFICIEL DE LA REPUblique FrançAIS [J.O.] [OFFICIAL GAZETTE OF FRANCE], July 25, 2012, p. 2427 (statement of Mme Pascale Crozon).

87. Because the statute is not retroactive, judicial pronouncements on the meaning of the new statute will have to await cases that arise on or after August 8, 2012. Cases involving sexual harassment presently being decided by the Court of Cassation involve situations from 2008 and earlier; current sexual harassment cases from the Courts of Appeals addressing issues of sexual harassment involve situations that arose three to four years before the enactment of the current student. See review of cases from Legifrance.gouv.fr, a public service that makes judicial decisions publicly available on an electronic basis (last visited October 6, 2013).

88. Loi 2002-73 du 17 janvier 2002 de modernisation sociale [Law 2002-73 of January 17, 2002 of social modernization], JOURNAL OFFICIEL DE LA REPUbliQUE FRANÇAISE [J.O.] [OFFICIAL GAZETTE OF FRANCE], Jan. 18, 2002, p. 1008, Art. 169, p. 1043. The provision was originally codified in Art. L 12249 before recodification of the Labor Code, effective May 1, 2008. Ordonnance No. 2007-329 du mars 2007 relative du code du travail (Mar. 12, 2007). 
publication of a book by psychiatrist Marie-France Hirigoyen titled Le harcèlement moral: la violence perverse au quotidien. ${ }^{89}$ She defined moral harassment in the context of the workplace as "all abusive conduct manifested particularly by behavior, words, acts, gestures or writings, which are capable of undermining the personality, dignity or the physical or mental integrity of a person, endangering his or her employment, or degrading the workplace atmosphere." 90 In addition to adopting her label for this experience, many of the concepts expressed in her definition of moral harassment were ultimately included in the legal prohibitions of the offense, including the notions of degradation of workplace conditions and endangering of employment, undermining physical and mental integrity, and harming dignity.

The provisions on moral harassment are contained in Art. 222-33-2 of the Penal Code and Art. L. 1152-1 to 1152-6 of the Labor Code. This portion of the Penal Code provides that:

The fact of harassing another by repeated acts having the purpose or effect of deteriorating his or her working conditions and that are likely to violate his or her rights and dignity, impair his or her physical or mental health or jeopardize his or her professional future, is punishable by two years' imprisonment and a fine of 30,000 euros. ${ }^{91}$

Similarly, article L. 1152-1 of the French Labor Code provides that "No

89. Marie-France Hirigoyen, LE HARCELEMENT MORAL : LA VIOLENCE PERVERSE AU QUOTIDIEN (Syros 1998). For a discussion of the origins of the French law of moral harassment, see Moral Harassment in the Workplace, supra note 10, at 114-19.

90. Hirigoyen, supra note 91, at 55. In the original French: «toute conduite abusive se manifestant notamment par des comportements, des paroles, des actes, des gestes, des écrits, pouvant porter atteinte à la personnalité, à la dignité ou à intégrité physique ou psychique d'une personne, mettre en péril l'emploi de celle-ci ou dégrader le climat de travail. »

91. CODE PÉNAL [C. PEN.] art. 222-33-2. In the original French: « Le fait de harceler autrui par des agissements répétés ayant pour objet ou pour effet une dégradation des conditions de travail susceptible de porter atteinte à ses droits et à sa dignité, d'altérer sa santé physique ou mentale ou de compromettre son avenir professionnel, est puni de deux ans d'emprisonnement et de $30000 €$ d'amende. " Before the enactment of the new Penal Code provision on sexual harassment, the criminal penalty associated with moral harassment, like that of sexual harassment, was one year's imprisonment and a fine of 15,000 euros. However, the penalty associated with moral harassment is not subject to enhancement based on aggravating circumstances, as is the penalty associated with sexual harassment. See discussion of sexual harassment penalties in note 48 , supra.

After the sexual harassment provision of the Penal Code was declared unconstitutional by the Constitutional Council, the Court of Cassation was asked to submit a QPC to the Council on the constitutionality of the Penal Code provisions on moral harassment. Both the criminal division and the social division of the Court of Cassation refused to do so, concluding that it was not necessary because the Constitutional Council had already declared those provisions to be in conformity with the Constitution in its decision of January 12, 2002 concerning the Social Modernization Act, Conseil constitutionnel [CC] [Constitutional Court] decision No. 2001-455 DC, Rec. 49. The Court of Cassation held that the Penal Code provision on moral harassment was not affected by the decision of the Constitutional Council concerning the sexual harassment provision. Cour de cassation [Cass.] [supreme court for judicial matters] crim., July 11, 2012, Bull. crim., No. 170, No. 11-88114, available at http:/ / www.legifrance.gouv.fr/affichJuriJudi.do?oldAction=rechJuriJudi\&idTexte=JURITEXT000026 181166\&fastReqId=722333599\&fastPos $=1$; Cour de cassation [Cass.] [supreme court for judicial matters] soc., July 11, 2012, Bull. civ. V, No. 220, No. 12-40051, available at http:/ / www.legifrance.gouv.fr/affichJuriJudi.do?oldAction=rechJuriJudi\&idTexte=JURITEXT000026 183102. 
employee shall be subjected to repeated actions of moral harassment, which have the purpose or effect of deteriorating working conditions and that are likely to violate his or her rights and dignity, impair his or her physical or mental health or jeopardize his or her professional future."92 The Labor Code contains additional provisions similar to the additional provisions relating to sexual harassment. For example, the provisions on moral harassment prohibit an employee from being discriminated against or subjected to adverse employment action for having submitted to or having refused to submit to repeated acts of moral harassment, or for having reported or having testified about those acts. ${ }^{93}$ Employers are also under an obligation to take "all necessary actions with a view of preventing acts of moral harassment." 94

Cases applying the Labor Code provisions on moral harassment confirm the statutory language indicating that repeated acts constitute moral harassment when they have the "purpose or effect" of the deterioration of working conditions, such that actionable moral harassment can exist without regard to the intention of the harasser; the social division (chambre sociale) of the Court of Cassation has so held.95 Interestingly, although the provision on moral harassment in the Penal Code uses exactly the same language with respect to "purpose or effect," in both an earlier and a subsequent decision, the criminal division of the Court of Cassation confirmed the holding of the court of appeals that the criminal offense of moral harassment must involve intentional action on the part of the perpetrator of harassment. ${ }^{96}$

92. CODE DU TRAVAIL [C. TRAV.] art. L. 1152-1 (In the original French: «Aucun salarié ne doit subir les agissements répétés de harcèlement moral qui ont pour objet ou pour effet une dégradation de ses conditions de travail susceptible de porter atteinte à ses droits et à sa dignité, d'altérer sa santé physique ou mentale ou de compromettre son avenir professionnel.»).

93. CODE DU TRAVAIL [C. TRAV.] art. L. 1152-2 ("No employee may be sanctioned, dismissed, or subjected to discriminatory measures for having submitted or having refused to submit to acts of repeated moral harassment or for having testified of those acts or having reported them."). In the original French : "Aucun salarié... ne peut être sanctionné, licencié ou faire l'objet d'une mesure discriminatoire, directe ou indirecte, ... pour avoir subi ou refusé de subir des agissements répétés de harcèlement moral ou pour avoir témoigné de tels agissements ou les avoir relatés. " The violation of this provision is punishable by one year's imprisonment and a fine of 3,750 euros. CODE DU TRAVAIL [C. TRAV.] art. L. 1155-2.

94. CODE DU TRAVAIL [C. TRAV.] art. L. 1152-4. In the original french : «L'employeur prend toutes dispositions nécessaires en vue de prévenir les agissements de harcèlement moral. »

95. Cour de cassation [Cass. soc.,] [supreme court for judicial matters] Nov. 10, 2009, Bull. civ. V, No. 248, No. 08-41497, available at http://www.legifrance.gouv.fr/ affichJuriJudi.do?idTexte=JURITEXT000021270373; Cour de cassation [Cass.] [supreme court for judicial matters] soc., Jan. 28, 2010, No. 08-42616, http://www.legifrance.gouv.fr/ affichJuriJudi.do?idTexte=JURITEXT000021768871. See Loïc Lerouge, La constitution du harcèlement moral au travail indépendamment de l'intention de son auteur, note sous Cass. Soc. 10 nov. $2009 \mathrm{n}^{\circ} 08-$ 41.497, Petites Affiches, $\mathrm{n}^{\circ}$ 28, 9 février 2010, p. 18-21 (discussing how the reliance of the Court of Cassation on the "purpose" or "effect" language of the Labor Code provision on moral harassment resulted in the conclusion that moral harassment exists without regard to the intention of the harasser, thereby significantly enlarging the scope of actions that might be found to be moral harassment.

96. Cour de cassation [Cass.] [supreme court for judicial matters] crim., June 21, 2005, Bull. crim., No. 187, p. 661, No. 04-86936, available at http:/ / www.legifrance.gouv.fr/ affichJuriJudi.do?idTexte= JURITEXT000007069102\&dateTexte=; Cour de cassation [Cass.] [supreme court for judicial matters] crim., June 8, 2010, No. 10-80570, http:/ / www.legifrance.gouv.fr/ 
This willingness of the Court of Cassation to allow the same language in the Penal Code and the Labor Code to be interpreted differently with respect to moral harassment contrasts sharply with the attitude of the Court toward the sexual harassment provisions. This suggests that the fact that criminal courts applying the Penal Code are likely to be more restrictive than labor courts applying the Labor Code will not result, as has been true of sexual harassment, in a restrictive reading of the moral harassment provisions of the Labor Code. In fact, the cases decided under the Labor Code provisions, as discussed below, seem to support this assumption. The relatively broader reading of the provisions on moral harassment as compared with the provisions on sexual harassment also likely reflects the fact that the majority of cases dealing with moral harassment have been decided by labor courts under the Labor Code, rather than by criminal courts under the Penal Code, unlike cases dealing with sexual harassment.

For example, the courts have confirmed that as long as the deterioration of working conditions has occurred, a claim of actionable moral harassment requires only that the harassing conduct is likely to cause the harms specified in the statute, not that it actually caused those harms. Accordingly, the criminal division of the Court of Cassation held that harassment need not take place within the context of a hierarchical relationship in order to violate the statute, in that moral harassment can be established even if the harasser is a workplace subordinate of the target of harassment without the actual authority to bring about harm to one's professional future. ${ }^{97}$

The social division of the Court of Cassation rejected the court of appeals' attempt to limit actionable moral harassment to acts that occur over an extended period of time, concluding that a subordinate who was subjected to degrading working conditions and denigrating comments over a short period of time could still establish the existence of moral harassment. ${ }^{98}$ However, the social division of

affichJuriJudi.do?oldAction=rechJuriJudi\&idTexte=JURITEXT000022457458\&fastReqId=1643918403\& fastPos=1 (noting the court of appeals reliance on the harasser's deliberate action exceeding his powers of management and its characterization of all of the elements of the offense, including that of intention on the part of the harasser).

See also Françoise Champeaux, Les mutations du harcèlement moral, 1482 SEMAINE SOCIALE LAMY 2 (2011) (discussing the duality of the penal law and the labor law of moral harassment with respect to the issue of intention, noting that the offense of harassment is an intentional offense, "un délit intentionnel, » with intent to commit the act of harassment being an element of the infraction); Fortis, supra note 85 (discussing duality of definition of moral harassment in the Labor Code and the Penal Code, given that Court of Cassation held that moral harassment can exist independent of the intention of the harasser, while the Penal Code retains as an element of moral harassment the existence of intentional or reckless conduct).

97. Cour de cassation [Cass.] [supreme court for judicial matters] crim., Dec. 6, 2011, Bull. crim., No. 249, No. 10-82266, available at http://www.legifrance.gouv.fr/affichJuriJudi.do ?oldAction=rechJuriJudi\&idTexte=JURITEXT000025119012\&fastReqId $=25775373 \&$ fastPos $=1$

(reversing decision of court of appeals that a subordinate's action of sending obscene e-mails to his female supervisor and engaging in other disruptive behavior, ultimately resulting in her suicide, could not constitute moral harassment without a showing of actual degradation of working conditions or compromise of her professional future and because he was her subordinate; court of cassation held that conduct must only be likely to have those effects to be actionable and that the fact that he was her subordinate was irrelevant to the establishment of the offense).

98. Cour de cassation [Cass.] [supreme court for judicial matters] soc., May 26, 2010, Bull. civ. V, 
the Court of Cassation did confirm that a single act is not sufficient to establish the existence of moral harassment, because the statutory language expressly requires that actions be repeated..$^{99}$

The social division of the Court of Cassation upheld the decision of the court of appeals to find the existence of moral harassment when a supervisor imposed on his subordinate constant pressure for him to quit his job and constant reproaches, and refused to communicate and give instructions for his work.100 Similarly, the social division of the Court of Cassation rejected the conclusion of the court of appeals that moral harassment had not been shown by a subordinate's claim that his supervisor was constantly on his back and controlled completely his starting and stopping work, refusing even to provide him time to go to the toilet and to wash his hands, on the grounds that he had not shown that the deterioration of his health was related to his working conditions; the Court of Cassation indicated that once the employee established facts from which the existence of moral harassment could be presumed, it was the employer's burden to establish the lack of moral harassment. ${ }^{101}$

Similarly, the social division of the Court of Cassation rejected the decision of the court of appeals that moral harassment had not been established in the case of an employee who was made to work seven days a week for nearly two years, sometimes for as long as twenty-one hours at a time, and was sent as many as thirty-three e-mails a day urging her to increase her rate of work, on the grounds that the court of appeals had not justified its decision by merely stating that the acts "in themselves" did not constitute moral harassment. ${ }^{102}$

The criminal division of the Court of Cassation confirmed the court of appeals' decision to convict operators of a supermarket of moral harassment

No. 111, No. 08-43152, available at http://www.legifrance.gouv.fr/affichJuriJudi.do

?oldAction $=$ rechJuriJudiEidTexte $=J U R I T E X T 000022279684 \mathcal{E}$ fastReqId $=63530855 \mathcal{E}$ fastPos $=2$.

99. Cour de cassation [Cass.] [supreme court for judicial matters] soc., Dec. 9, 2009, Bull. civ. V, No. 280, No. 07-45521, available at http:/ / www.legifrance.gouv.fr/affichJuriJudi.do ?oldAction=rechJuriJudi\&idTexte=JURITEXT000021472025 (ruling that single act of demotion of employee from business representative to secretary could not constitute moral harassment because statutory requirement of repeated acts was not satisfied).

100. Cour de cassation [Cass.] [supreme court for judicial matters] soc., Nov. 10, 2009, Bull. civ. V, No. 247, No. 07-45321, available at http:/ / www.legifrance.gouv.fr/affichJuriJudi.do?oldAction $=$ rechJuriJudi\&idTexte=JURITEXT000021270312\&fastReqId $=85430940 \&$ fastPos $=1$.

101. Cour de cassation [Cass.] [supreme court for judicial matters] soc., Apr. 30, 2009, Bull. soc. V, No. 120, No. 07-43219, available at http:/ / www.legifrance.gouv.fr/affichJuriJudi.do ?oldAction=rechJuriJudi\&idTexte=JURITEXT000020577017\&fastReqId=84221230\&fastPos=1. This allocation of the burden of proof is dictated by statute. Article L. 1154-1 of the Labor Code requires that the employee complaining of harassment establish facts from which the existence of harassment can be presumed and that the party defending against the claim prove that those facts do not constitute moral harassment and that the employer's actions were justified by objective factors unrelated to any harassment. CODE DU TRAVAIL [C. TRAV.] art. L. 1154-1 (In the original French: «le salarié établit des faits qui permettent de présumer l'existence d'un harcèlement » and « [a]u vu de ces éléments, il incombe à la partie défenderesse de prouver que ces agissements ne sont pas constitutifs d'un tel harcèlement et que sa décision est justifiée par des éléments objectifs étrangers à tout harcèlement »).

102. Cour de cassation [Cass.] [supreme court for judicial matters] soc., Sept. 22, 2010, No. 0941.495.http:/ / www.legifrance.gouv.fr/affichJuriJudi.do?oldAction=rechJuriJudi\&idTexte $=$ JURITEXT000022858175\&fastReqId=1882335558\&fastPos=1. 
based on their actions toward a number of employees, including whistling to call employees, demeaning and criticizing them in front of customers, accusing one employee of maintaining a sexual relationship with a store manager and another of being an alcoholic, and isolating employees from each other. ${ }^{103}$

The provisions on moral harassment in the Penal and Labor Codes share with the corresponding sexual harassment provisions the concept of the violation of the dignity of the employee subjected to harassment, but contain additional concepts not shared by the definition of sexual harassment. The moral harassment provisions focus on the somewhat more tangible harms of deterioration of working conditions, harm to an employee's mental and physical health, and injury to one's professional future, while the sexual harassment provisions focus on degrading and humiliating conduct and the creation of an intimidating, hostile, or offensive environment. Accordingly, while the underlying basis of the sexual harassment provisions seems to be focused on preventing harm to dignity, the underlying basis of the moral harassment provisions appears to be an interest in protecting an employee from unfavorable workplace conditions and preserving his or her employment opportunities.

\section{The Prohibition of Discriminatory Harassment}

A third prohibition on harassment is found in the Labor Code in Article L. 1132-1, prohibiting harassment as a form of discrimination. That provision generally prohibits an individual, in the context of employment, from being subjected to "discriminatory measures... by reason of ... his or sex" or other protected characteristics, including age, sexual orientation or gender identity, ethnicity, religious beliefs, or disability, among others. ${ }^{104}$ Discrimination is expressly defined in that article to include discrimination as defined in the law of May 27, 2008, which adapted certain European Union Directives concerning discrimination into French national law. ${ }^{105}$ In particular, discrimination is defined in that law to include: "[a]ny act linked to one of the motives mentioned in the first paragraph and any act with a sexual connotation, suffered by a person and having the purpose or the effect of violating his or her dignity or creating an intimidating, hostile, degrading, humiliating or offensive environment."106

103. Cour de cassation [Cass.] [supreme court for judicial matters] crim., May 26, 2009, No. 0887.874, http://www.legifrance.gouv.fr/affichJuriJudi.do?oldAction=rechJuriJudi\&idTexte=JURITEX T000020767462\&fastReqId=816875523\&fastPos=1 (denying the store operators relief on the first grounds for appeal).

104. CODE DU TRAVAIL [C. TRAV.] art. L. 1132-1 (In the original French : « aucune salarié ... ne faire l'objet d'une mesure discriminatoire ... en raison ... de son origine, de son sexe, de ses mœurs, de son orientation ou identité sexuelle, de son âge, de sa situation de famille ou de sa grossesse, de ses caractéristiques génétiques, de son appartenance ou de sa non-appartenance, vraie ou supposée, à une ethnie, une nation ou une race, de ses opinions politiques, de ses activités syndicales ou mutualistes, de ses convictions religieuses, de son apparence physique, de son nom de famille ou en raison de son état de santé ou de son handicap. »).

105. Loi 2008-496 du 27 mai 2008 portant diverses dispositions d'adaptation au droit communautaire dans le domaine de la lutte contre les discriminations [English translation], JOURNAL OfFICIEL DE LA REPUbliQue FRANÇAise [J.O.] [OFFICIAL GAZETTE OF FRANCE], May 27, 2008.

106. Id. (In the original French: "Tout agissement lié à l'un des motifs mentionnés au premier alinéa et tout agissement à connotation sexuelle, subis par une personne et ayant pour objet ou pour effet de porter atteinte à sa dignité ou de créer un environnement hostile, dégradant, humiliant ou 
As with the provisions on sexual and moral harassment, the Labor Code contains other provisions with respect to discriminatory harassment. Employees may not be discriminated against or subject to adverse action in connection with employment for having testified about or reported acts of discrimination. ${ }^{107}$ However, the Labor Code provisions on discriminatory harassment do not include a provision imposing on employers the obligation to take action to prevent acts of discrimination or discriminatory harassment, as is imposed on employers with respect to sexual and moral harassment.

The European Union directives incorporated into French national law include Directive 2006/54/EC, which makes clear that harassment, including sexual harassment, is a form of discrimination. ${ }^{108}$ That directive defines "harassment" as existing "where unwanted conduct related to the sex of a person occurs with the purpose or effect of violating the dignity of a person, and of creating an intimidating, hostile, degrading, humiliating or offensive environment."109 "Sexual harassment" is defined in that directive as existing "where any form of unwanted verbal, non-verbal or physical conduct of a sexual nature occurs, with the purpose or effect of violating the dignity of a person, in particular when creating an intimidating, hostile, degrading, humiliating or offensive environment."110 Accordingly, the more general term "harassment" would seem to encompass non-sexual conduct motivated by or related to an individual's sex or gender, while the narrower term of "sexual harassment" would seem to be limited to conduct with a sexual connotation, but without any express requirement that the conduct be shown to have been motivated by or be related to a person's sex or gender.

Other European Union directives dealing with discrimination that were also incorporated into French national law by the law of May 27, 2008 specify that acts motivated by or linked to other protected characteristics also constitute

offensant »). The French Penal Code also contains a prohibition on acts of discrimination, but that provision does not contain a definition of or prohibition on discriminatory harassment. That provision defines as discrimination any distinction between individuals because of their sex or other characteristics, including origin, ethnicity, religious beliefs, disability, or sexual orientation or gender identity, as well as others. In the original French: "Constitue une discrimination toute distinction opérée entre les personnes physiques à raison de leur origine, de leur sexe, de leur situation de famille, de leur grossesse, de leur apparence physique, de leur patronyme, de leur état de santé, de leur handicap, de leurs caractéristiques génétiques, de leurs moeurs, de leur orientation ou identité sexuelle, de leur âge, de leurs opinions politiques, de leurs activités syndicales, de leur appartenance ou de leur non-appartenance, vraie ou supposée, à une ethnie, une nation, une race ou une religion déterminée.» CODE PENAL [C. PEN.] art. 225-1.

107. CODE DU TRAVAIL [C. TRAV.] art. L. 1132-3 (“No employee may be sanctioned, dismissed, or subjected to discriminatory measures for having testified of acts defined in articles L. 1132-1 and L. 1132-2 or for having reported them."). In the original French: "Aucun salarié ne peut être sanctionné, licencié ou faire l'objet d'une mesure discriminatoire pour avoir témoigné des agissements définis aux articles L. 1132-1 et L. 1132-2 ou pour les avoir relatés. »

108. Directive 2006/54/EC, of the European Parliament and of the Council of 5 July 2006 on the implementation of the principle of equal opportunities and equal treatment of men and women in matters of employment and occupation, 2006 O.J. (L 204) 23. That directive provides that "[h]arassment and sexual harassment are contrary to the principle of equal treatment between men and women and constitute discrimination on grounds of sex for the purposes of this Directive."

109. Id. at 26.

110. Id. at 27. 
harassment and therefore discrimination. Council Directive 2000/43/EC of June 29, 2000 implementing the principle of equal treatment between persons irrespective of racial or ethnic origin defines harassment as a form of discrimination that occurs "when an unwanted conduct related to racial or ethnic origin takes place with the purpose or effect of violating the dignity of a person and of creating an intimidating, hostile, degrading, humiliating or offensive environment."111 Similarly, Council Directive 2000/78/EC of November 27, 2000, establishing a general framework for equal treatment in employment and occupation, defines harassment as a form of discrimination on the basis of religion or belief, disability, age, or sexual orientation "when unwanted conduct related to any of the grounds... takes place with the purpose or effect of violating the dignity of a person and of creating an intimidating, hostile, degrading, humiliating or offensive environment." 112

The European Union directives and their approach of defining harassment as a form of discrimination appears to have been heavily influenced by AngloSaxon approaches to harassment law, including the law of the United States. It is impossible to miss the similarity in language between the U.S. Equal Employment Opportunity Commission's definition of what is known as "hostile environment" sexual harassment and the definition of harassment contained in the European Directives. The regulations of the EEOC define "sexual harassment" as including "[u]nwelcome sexual advances, requests for sexual favors, and other verbal or physical conduct of a sexual nature constitute sexual harassment when... such conduct has the purpose or effect of unreasonably interfering with an individual's work performance or creating an intimidating, hostile or offensive working environment."113 While there are obviously important differences between those definitions, most importantly the inclusion in the European Directives of the notion of violation of dignity, it seems clear that the European Directives were modeled at least in part on U.S. law. ${ }^{114}$

The Labor Code's definition of discriminatory harassment appears to create a two-pronged definition of harassment. First, harassment is defined as acts linked or related to one of the various discriminatory motives prohibited by the law, including discrimination on the basis of sex. Accordingly, acts that are

111. Council Directive 2000/43/EC, of 29 June 2000 Implementing the Principle of Equal Treatment between Persons Irrespective of Racial or Ethnic Origin, art. 2, 2000 O.J. (L 180) 22, 24.

112. Council Directive 2000/78/EC, of 27 November 2000 Establishing a General Framework for Equal Treatment in Employment and Occupation, arts. 1, 2, 2000 O.J. (L 303) 16, 18-19.

113. 29 C.F.R. § 1604.11(a) (2012).

114. In connection with the enactment of the new sexual harassment law in France, legislators recognized this similarity and expressed apparent discomfort that the European Union directives were being used as a model for that new law, indicating the inconsistency between those directives equating sexual harassment with discrimination, while French law generally does not. See Sénat, Session Extraordinaire de 2011-2012, Séance du mercredi 11 juillet 2012, Compte rendu intégral, JOURNAL OFFICIEL DE LA REPUBLIQUE FRANÇAIS [J.O.] [OFFICIAL GAZETTE OF FRANCE], July 12, 2012, p. 2032 (statement of Mme Éliane Assassi) (noting that the United States' approach to sexual harassment as a form of discrimination has echos in Europe and resulted in the text of the directives/ In French, «Dans le pays anglo-saxons, notamment aux États-Unis, les actes de «harcèlement sexuel » ont toujours été appréhendés sous l'angle de la "discrimination sexuelle». Cette approche du harcèlement comme forme de discrimination fondée sur le sexe, a eu des échos en Europe et s'est traduite dans le texte de la directive. »). 
motivated by a prohibited basis and that violate a person's dignity or create a hostile or offensive environment constitute prohibited harassment, regardless of whether those acts have a sexual connotation. In addition, however, all acts that have a sexual connotation, apparently regardless of whether they are proven to be linked to the prohibited motive of sex, are defined as harassment, as long as they have the purpose or effect of violating the person's dignity or creating a hostile or offensive environment. It is not clear whether the decision to define acts with a sexual connotation as discriminatory harassment under this provision, without an explicit showing of the motivation behind that harassment, represents an intent not to require evidence of discrimination for these types of harassment claims or merely a belief that acts with a sexual connotation are necessarily linked or related to a prohibited motivation, that of sex or gender.

The Labor Code provision on discriminatory harassment would seem to reach much, but not all, of the same conduct that is encompassed within the definitions of sexual and moral harassment contained in the other portions of the Penal Code and Labor Code addressed above, while some conduct would seem to violate this provision but would not be covered under those other definitions. Accordingly, this provision seems to be, at the same time, both broader and narrower in scope than the other definitions of sexual and moral harassment. This provision is narrower in the sense that, at least with respect to harassment that does not consist of conduct with a sexual connotation or of a sexual nature, the harassing conduct must be shown to have been motivated by one of the listed grounds of discrimination in order to be actionable under this provision. Accordingly, acts of moral harassment will presumably fall within the scope of the provision on discriminatory harassment only when they are motivated by one of the grounds of discrimination prohibited by the Labor Code.

At the same time, while the other definitions of moral harassment explicitly require repeated actions, and the other definitions of sexual harassment require repeated actions when the conduct is not directed at obtaining sexual conduct, the definition of discriminatory harassment does not expressly require that actions be repeated, to the extent that a single act might be sufficient to violate one's dignity or create a hostile or offensive environment. Accordingly, this provision would seem to cover some instances of both sexual and moral harassment based on a single, very serious, but not repeated, act considered sufficient to violate the dignity of an individual or otherwise adversely affect his or her workplace conditions or environment.

There have been few, if any, cases concerning harassment decided under this definition of harassment in the Labor Code. The definition of discriminatory harassment was adopted into French national law at the insistence of the European Union and it appears not to have been embraced by either litigants or the courts. It seems likely that this is the case because of the separation in French law generally between harassment and discrimination.

\section{USE OF FRENCH HARASSMENT LAW AS A MODEL FOR A CLAIM OF HARASSMENT UNDER UNITED STATES LAW}

There is a certain irony in looking to French harassment law as a potential model for a gender-neutral claim of harassment in the United States. First, as explained above, the new definition of sexual harassment in France was inspired 
in part by the European Directives on harassment, which were in turn inspired by Anglo-Saxon notions of harassment, including those of the United States. Accordingly, in some sense, the United States would be looking for inspiration from a legal concept inspired in part by its own legal system. On the other hand, the European Union directives, and France, in turn, have introduced a new concept into its harassment law, that of "dignity," which the United States' approach has not encompassed.

A second source of irony in using French harassment law as a model for a claim of harassment in the United States is that legislators and others in France have often expressed concern that French sexual harassment law not reflect the perceived "excesses" of the United States' sexual harassment law. ${ }^{115}$ Accordingly, looking to French law to expand upon the concept of sexual harassment in the United States might well strike the French as an inappropriate use of their law.

Finally, looking to French law as a potential model for a claim of harassment within the United States will also require overcoming a similar resistance on the part of some lawmakers in the United States. Some legislators and members of the judiciary in the United States have shown a resistance to looking to foreign law to inform their understanding of law in the United States. 116 This resistance seems to be wrongheaded and provincial; to paraphrase United States Supreme Court Justice Stephen Breyer, it seems that the worst that can happen is that nations, courts, and legislatures "might learn something"117 from each other.

What the United States might learn from France is that a focus on the

115. See Abigail C. Saguy, What is Sexual Harassment? From Capitol Hill to the SorbonNe 16, 38 (2003) (discussing the way the French press has trivialized sexual harassment by focusing on American "excesses" and "puritanism," and how proponents of the original sexual harassment legislation in France encountered resistance among legislators "who seemed intent on discrediting the bill by appealing to anti-American rhetoric, arguing that passing a sexual harassment law in France would have the undesirable effect of importing 'American excesses' of litigiousness, puritanism, and the Battle of the Sexes"). See also Assemblée Nationale, Session Extraordinaire de 2011-2012, Séances du mardi 24 juillet 2012, Compte rendu intégrale, JOURNAL OFFICIEL DE LA REPUBLIQUE FRANÇAIS [J.O.] [OFFICIAL GAZETTE OF FRANCE], July 25, 2012, p. 2407 (statement of M. Georges Fenech) (without directly invoking the name of the United States, he expressed the concern with using language from the European directives on hostile and offensive environments because it "comes from a culture marked by moral strictness and puritanism" / In French: "Certes, cette terminologie est issue d'une directive européenne mais l'on peut se demander, j'ose le dire, si elle n'est pas surtout issue d'une culture marquée par le rigorisme et le puritanisme. »).

116. See Martha Minow, The Controversial Status of International and Comparative Law in the United States, 52 HARV. INT'L L.J. Online 1, 2-3 (2010),

http://www.harvardilj.org/2010/08/online_52_minow/ (describing controversy over reference of the law of other nations as recent, with a reference to the need to consult the law of other nations found in the Federalist Papers and frequent citations to the law of other nations in early decisions of the United States Supreme Court). The recency of the controversy, however, has not affected the ferocity of the opposition to references to foreign law; some members of Congress have suggested that judges who cite to foreign law should be impeached. Id. at 4.

117. Id. at 5 (citing Jesse J. Holland, Justice Breyer Says Debate Over Foreign Law is Irrelevant, LAW.COM, (Apr. 2, 2010), http://www.law.com/jsp/scm/PrintFriendly.jsp?id=1202447364424). Justice Ruth Bader Ginsburg has also challenged the notion that the United States should not seek to learn from the law of other countries: "We are the losers if we neglect what others can tell us about endeavors to eradicate bias against women, minorities, and other disadvantaged groups." Justice Stephen Breyer, Keynote Address, 97 AM. SOC'Y INT'L L. PROC. 265 (2003) (quoting Ginsburg, J.). 
discriminatory aspects of sexual harassment-the ways in which sexual harassment is spawned in part by the existence of gender inequality in the workplace, as well as the ways in which the existence of sexual harassment in the workplace creates more gender inequality - is not the only way to approach issues of sexual harassment. While sexual harassment raises issues of gender equality, it also raises issues of basic respect for human dignity and autonomy. To the extent that those issues of human dignity and autonomy are not directly tied to gender - that women (and men) who are sexually harassed suffer harm to their dignity and autonomy not because they are women (or men) but because they are human - a consideration of harms to dignity, separate from a focus on considerations of gender equality, might well provide an independent ground for condemning sexual harassment.

To understand whether this is true, it is necessary to understand what is meant by "dignity" as used in the French laws of sexual and moral harassment. To make this determination, one might look to a number of sources, including how that term is used in other legal and similar documents in France and within European Union nations more generally, as well as the commonly understood meaning of that term, both in France and elsewhere.

As the term "dignity" is used more generally, the concept of dignity may not be as much a single concept as a number of related concepts. ${ }^{118}$ One meaning given to dignity seems tied to notions of equality, such that each individual is entitled to the equal dignity as every other individual. ${ }^{119}$ This concept of dignity is reflected in the Universal Declaration of Human Rights, which indicates in Article 1 that: "All human beings are born free and equal in dignity and rights." 120 Under this meaning of the term "dignity," discrimination itself would violate dignity, by denying individuals their entitlement to equal respect for their dignity and rights.

Another meaning given to the concept of dignity is that of autonomy or selfdetermination, such that individuals have the right to make their own decisions about how to live their lives. ${ }^{121}$ Still another meaning of the concept of dignity is the notion of dignity as meriting respect for one's person. This is a common meaning given to the concept of dignity, such that humiliation or degradation counts as a violation of human dignity. ${ }^{122}$

The concept of "dignity" is recognized in the European Union Charter of Fundamental Rights, in Article 1 of Chapter 1 of that document: "Human dignity

118. The right to dignity can also be understood, and is understood in some countries, as a positive right that provides citizens with a right to a certain level of subsistence consistent with notions of human dignity. See ERIN DALY, DIGNITY RIGHTS: COURTS, CONSTITUTIONS, AND THE WORTH OF THE HUMAN PERSON 54-70 (2013) (discussing the theory of "material dignity" and its role in the constitutions and jurisprudence of various nations). This, however, does not appear to the way in which the term "dignity" is used within the new French harassment provisions.

119. See id. at 34-35 (detailing the "equality" theory of dignity).

120. Universal Declaration of Human Rights, G.A. Res. 217 (III) A, art. 1, U.N. Doc. A/RES/217(III) (Dec. 10, 1948).

121. See DALY, supra note 125, at 38-44 (linking autonomy to "full personality development").

122. See Michael Rosen, Dignity: ITS History AND MEANING 127 (2012) ("[T]he idea that humiliation or degradation counts as a violation of human dignity has a very good claim to be universal even though the practices by which that may be expressed vary."). 
is inviolable. It must be respected and protected."123 The Commentary of the Charter of Fundamental Rights of the European Union refers to dignity as a foundational value and indicates that the term "human dignity" in the Charter is a legal term. The Commentary notes certain definitions given to the term "human dignity" in case law within the European Union, including the following definition by the German Federal Constitutional Court: "The term 'human dignity' means that the human being has a right to 'social value and respect.'"124 The Commentary declares that: "Any measure impairs Article 1 if it brings into contempt the value which a human being has by his/her being a person. Measures of this kind would be humiliation, branding, outlawing or other behaviour which deprives the human person of the right to recognition as a human being."125 Accordingly, it appears that the concept of dignity, as used within the European Union generally, encompasses at least the concept of dignity as respect and freedom from humiliating or degrading conduct.

The dictionary definition of the French word "dignite » is " respect que mérite quelqu'un » (in English, "respect that is deserved by someone"), 126 as well as « respect de soi » (in English, "self respect"). ${ }^{127}$ It appears that the common meaning of dignity in the French language includes at least the concept of dignity as respect and freedom from humiliation.

The term "dignity" does not appear in the current French Constitution, that of October 4, 1958, although the Constitution does refer to other rights considered to be basic, such as liberty, equality, and fraternity. ${ }^{128}$ The concept of

123. Charter of Fundamental Rights of the European Union 2000/C 364/01, 2000 O.J. (C 364) 1, 9. As originally enacted, the Charter of Fundamental Rights of the European Union had no formal legal status under European Union law, the European Commission indicated that it would treat the Charter as if it were binding and the European Parliament indicated that it would pay particular attention to whether proposed legislation was in conformity with the Charter. European Union Network of Independent Experts on Fundamental Rights, Commentary of the Charter of Fundamental Rights of the European Union 15 (June 2006), http://ec.europa.eu/justice/fundamentalrights/files/networkcommentaryfinal_en.pdf. However, with the entry into force of the Treaty of Lisbon, the Charter became legally binding on the E.U. itself and its member nations. Treaty of Lisbon, Official Journal of the European Union, c. 306, vol. 50 (Dec. 17, 2007).

124. European Union Network of Independent Experts on Fundamental Rights, Commentary of the Charter of Fundamental Rights of the European Union 26 (June 2006) (citing Sammlung der Entscheidungen des Bundesverfassungsgerichts [BVerfGE] [Reports of the Decisions of the Federal Constitutional Court], Oct. 20, 1992, 87, 209.)).

125. Id. at 28.

126. Paul Robert, Le Petit Robert, Dictionnaire AlphabetiQue et ANAlogiQue de la Langue FRANÇAISE 482 (1967). One example given in the dictionary for this meaning is «principe de la dignité de la personne humaine » (in English, principle of the dignity of the human person).

127. Id. One of the examples of this meaning is "manquer de dignité " (In English, "lack of dignity").

128. 1958 CONST. Preamble (Fr.), available at http://www.conseil-constitutionnel.fr/conseilconstitutionnel/english/constitution/constitution-of-4-october-1958.25742.html (English version) [hereinafter 1958 Constitution]. The Preamble to the 1958 Constitution declares that: "The French people solemnly proclaim their attachment to the Rights of Man and the principles of national sovereignty as defined by the Declaration of 1789, confirmed and complemented by the Preamble to the Constitution of 1946, and to the rights and duties as defined in the Charter for the Environment of 2004." Dignity is also not mentioned in the Preamble to the Constitution of 27 October 1946. 1946 CONST. Preamble (Fr.), available at http://www.conseil-constitutionnel.fr/conseilconstitutionnel/francais/la-constitution/les-constitutions-de-la-france/constitution-de-1946-ive- 
dignity, however, has been incorporated into French law, including into the Penal Code. In addition to the use of the French word "dignite » in the Penal Code provisions on sexual and moral harassment, the Penal Code also contains a chapter titled "Attacks on the dignity of the person" (In French, " Des atteintes à la dignité de la personne »), ${ }^{129}$ which includes a prohibition on discrimination, including a prohibition on discrimination against a person who submits or refuses to submit to sexual harassment. ${ }^{130}$ Also included within this chapter is a prohibition on human trafficking, ${ }^{131}$ a prohibition on forcing another to conceal his or her face by reason of sex,132 a prohibition on the promotion of prostitution, ${ }^{133}$ a prohibition on the exploitation of begging, ${ }^{134}$ and a prohibition on hazing. ${ }^{135}$

It would appear that the concept of dignity within French law includes notions of equality of treatment, as reflected in the prohibitions of different forms of discrimination, as well as the notion of respect or freedom from humiliating and degrading behavior, as reflected in the prohibitions of human trafficking, the promotion or exploitation of prostitution and begging, and hazing. The prohibition of hazing makes specific reference to humiliating and degrading acts. It is also possible that the prohibition of human trafficking and on forcing another to conceal his or her face by reason of sex is also aimed at the notion of dignity as autonomy.

The concept of dignity as respect and freedom from humiliating and degrading behavior seems to be the meaning of "dignity" that has been incorporated into the new French sexual harassment provisions, which prohibit

republique.5109.html The term "dignités " is found in the French version of the Declaration of the Rights of Man and the Citizen of August 26, 1789, in Article VI, which declares that "Tous les citoyens étant égaux à ses yeux, sont également admissibles à toutes dignités, places et emplois publics, selon leur capacité, et sans autre distinction que celle de leurs vertus et de leurs talents. ». Déclaration des Droits de L'Homme et du Citoyen de 1789, available at http://www.assembleenationale.fr/histoire/dudh/1789.asp [hereinafter French Declaration]. However, in the English version of the Declaration, made available on the website of the Conseil Constitutionelle (Constitutional Council), that portion of the Declaration is translated as: "All citizens, being equal in its eyes, shall be equally eligible to all high offices, public positions and employments, according to their ability, and without other distinction than that of their virtues and talents." Déclaration des Droits de L'Homme et du Citoyen de 1789, available at http://www.conseilconstitutionnel.fr/conseil-constitutionnel/root/bank_mm/anglais/cst2.pdf (English version). See also ROBERT, supra note 133 (defining «dignité » as "fonction, titre or charge qui donne à quelqu'un un rang eminent »/duties, title, or responsibility that gives someone a high rank). Accordingly, it does not appear that the Declaration refers to human dignity. By contrast, in the first and second articles of the Declaration, reference is made to principles of equality and liberty. French Declaration, arts. 2-3.

129. See generally CODE PÉNAL [C. PÉN] (Chapter V, titled "Attacks on the Dignity of the Person," is found within Title II, titled "Attacks on the Human Person" (in French, "Titre II : Des atteintes à la personne humaine »)). This is found within Book II, "Crimes and misdemeanors against persons" (In French, «Livre II : Des crimes et délits contre les personnes »).

130. Id. arts. 225-1 to 225-4. The prohibition on discrimination against a person who submits to or refuses to submit to sexual harassment is found in CODE PÉNAL [C. PÉN] art. 225-1-1.

131. Id. arts. 225-4-1 to 225-4-9.

132. Id. art. 225-4-10.

133. Id. arts. $225-5$ to $225-12$.

134. Id. arts. 225-12-5 to 225-12-7.

135. Id. arts. 225-16-1 to 226-16-3. 
the use of words or behavior with a sexual connotation against an individual, "which undermine his or her dignity by reason of their degrading or humiliating nature."136

The concept of dignity, while not foreign to the law of the United States, has not played the central role in U.S. law occupied by other foundational concepts. The Declaration of Independence by the thirteen united States of America refers to equality, liberty, and happiness, but not to "dignity" - at least not directly. ${ }^{137}$ The word "dignity" is also not found in the Constitution of the United States. ${ }^{138}$ This is not really surprising, because the concept of dignity as a foundational human right is relatively modern, dating from the late 1940s, after World War II. 139

On the other hand, courts in the United States, including the United States Supreme Court, have invoked the concept of human dignity in determining the proper application of constitutional provisions. This reliance on the concept of dignity seems to correspond to the broader global focus on dignity as a foundational human right, following World War II. ${ }^{140}$ During the latter half of the $20^{\text {th }}$ century and the first decade or so of the $21^{\text {st }}$ century, the United States Supreme Court began to recognize that dignity was implicated in a number of contexts, including issues of discrimination, privacy, and speech. ${ }^{141}$

An analysis of the manner in which Supreme Court justices have invoked the concept of dignity suggests that they have understood dignity as involving all three of the potential definitions of the term "dignity" described above: equality, autonomy, and respect. In some cases, equality has appeared to be the focus of the Court's discussion of dignity, while in other cases, the members of the Court seemed to focus more on issues of autonomy or respect.

For example, the Court in Lawrence v. Texas, in an opinion written by Justice Kennedy striking down a state statute criminalizing certain same-sex sexual conduct, seemed to focus more on the notion of dignity as equality when it noted that criminalization of such conduct even as a low-level misdemeanor, particularly when similar sexual conduct between members of the opposite sex was not prohibited, harmed the dignity of those so charged and convicted. ${ }^{142}$ The focus on dignity as equality is even more clear in the case of J.E.B. v. Alabama, ${ }^{143}$ in which then Justice Blackman wrote an opinion on behalf of the Court holding

136. Id. art. 222-33-I ; CODE DU TRAVAIL [C. TRAV] art. L. 1153-1 (In French, « qui soit portant atteinte à sa dignité en raison de leur caractère déradant ou humiliant »).

137. THE DECLARATION OF INDEPENDENCE para. 2 (U.S. 1776).

138. U.S. CONST.

139. See ROSEN, supra note 129, at 2 (noting that dignity played a "vital role" in important documents from the 1940s, including the U.N. Universal Declaration of Human Rights); see also DALY, supra note 125, at 1 ("Until the late twentieth century, there was no right to dignity. . All that changed in the aftermath of the Second World War.").

140. See generally DALY, supra note 125, at 82-100 (describing the beginnings of the use of the concept of dignity in opinions of the United States Supreme Court, in the wake of World War II).

141. Id. at 90-96.

142. See Lawrence v. Texas, 539 U.S. 558, 575 (2003) (“Equality of treatment and the due process right to demand respect for conduct protected by the substantive guarantee of liberty are linked in important respects, and a decision on the latter point advances both interests.").

143. 511 U.S. 127 (1994). 
that the use of peremptory challenges to exclude men from a jury considering a paternity child support action violated the Equal Protection Clause because striking male jurors simply because of their gender "denigrates the dignity of the excluded juror." 144

In other cases, however, dignity as autonomy or as respect seems more the focus of the Court's analysis. Indeed, the cases suggest that not all the justices of the Court perceive "dignity" to have the same meaning or at least the same meaning in the same cases. In Indiana v. Edwards, 145 involving the claim of a mentally ill criminal defendant who had been denied the right of selfrepresentation in his criminal trial, both the majority opinion by Justice Breyer and the dissent by Justice Scalia invoked the concept of dignity in support of their respective, and opposite, positions on the legal issue. Justice Breyer for the Court indicated that although interests in dignity and autonomy are the basis of the right of self-representation, allowing a defendant who lacks the mental capacity to conduct his own defense will not "affirm [his] dignity" because "the spectacle that could well result from his self-representation at trial is at least as likely to prove humiliating as ennobling." 146 Accordingly, while the majority of the Court seemed to define dignity, at least in part, as freedom from humiliation, Justice Scalia argued that the relevant issue of dignity underlying the right of self-representation was instead autonomy. He indicated that the "loss of 'dignity' the right is designed to prevent is not the defendant's making a fool of himself by presenting an amateurish or even incoherent defense," but was instead "the supreme human dignity of being master of one's fate rather than a ward of the State - the dignity of individual choice."147 However, even Justice Scalia, in his dissenting opinion in the case of National Treasury Employees Union v. Von Raab, ${ }^{148}$ dealing with the constitutionality of a program of drug testing in federal employment, seemed to define the concept of dignity in terms of freedom from humiliation. He called the program of drug testing, which required monitoring of the process of urination, to be "particularly destructive of privacy and offensive to personal dignity." 149 And he argued that not only these employees but the entire society would suffer from this "affront to . . dignity":

Those who lose because of the lack of understanding that begot the present exercise in symbolism are not just the Customs Service employees, whose dignity is thus offended, but all of us - who suffer a coarsening of our national manners that ultimately give the Fourth Amendment its content, and who become subject to the administration of federal officials whose respect for our privacy can hardly be greater than the small respect they have been taught to have for their own. ${ }^{150}$

Accordingly, an incorporation of the concept of dignity into the law of sexual harassment would not seem to be inconsistent with the values recognized by American courts, particularly with respect to the notion of dignity as the right

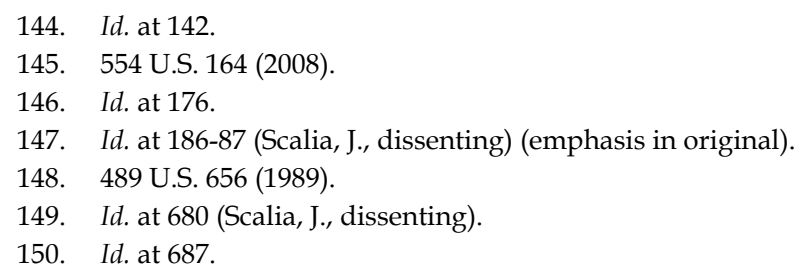


to be free from certain forms of disrespectful, humiliating, and degrading conduct. While the concept of dignity has generally been recognized by the courts in connection with their interpretation of constitutional provisions, there is no reason that protection for dignity could not be incorporated into statutory protections against sexual harassment, as the notion of equality has been incorporated into statutory protections.

A number of lower courts ${ }^{151}$ have recognized that sexual harassment can implicate the dignity interests of the individuals subjected to sexual harassment in a number of different contexts. The federal judge in Gallagher v. Delaney, 152 interpreting Title VII of the Civil Rights Act of 1964, noted that the prohibition against workplace sexual harassment was based at least in part on considerations of dignity:

[N]o principled argument supports the view that sex-based offensive behavior in the workplace is immune from remedy simply because it may be culturally tolerated outside of the workplace. The purpose of Title VII is not to import into the workplace the prejudices of the community, but through law to liberate the workplace from the demeaning influence of discrimination, and thereby to implement the goal of human dignity and economic equality in employment. ${ }^{153}$

Similarly, a federal bankruptcy judge agreed that a judgment of sexual harassment against a former employer was not dischargeable in bankruptcy because the injury was malicious: "Sexual harassment is not only illegal, but so morally reprehensible and degrading to one's personal dignity that the harasser's conduct cannot possibly be considered anything other than 'wrongful and without just cause or excuse.'"154 In the context of a state court judge being disciplined for his sexually harassing behavior toward his law clerk, the New Jersey Supreme Court indicated that the conduct was "personally offensive to his employee and inimical to her dignity, privacy, and emotional well-being." 155

In the context of a claim by a male prison inmate of sexual harassment by a female prison guard with whom he had had a prior romantic but not sexual relationship, the federal appeals court judge reversed the trial court's grant of summary judgment against the inmate on his Eighth Amendment claim; the

151. Even the United States Supreme Court seems to have recognized a connection between sexual harassment and dignity, although the precise nature of that connection is not altogether clear from the language of the case. See Oncale v. Sundowner Offshore Services, Inc., 523 U.S. 75, 77 (1998). In a case involving claims of same-sex sexual harassment in which the male plaintiff had alleged that he was threatened with rape and had a bar of soap shoved up his rectum by his male supervisors and co-workers, Justice Scalia on behalf of the Court noted that "in the interest of both brevity and dignity" the facts would be described only generally. Id. It is not entirely clear, however, whether Justice Scalia was concerned with Joseph Oncale's dignity or the dignity of the Court. Justice Scalia, however, did note that Oncale had been subjected to "sex-related, humiliating actions." Id.

152. 139 F.3d 338 (2d Cir. 1998).

153. Id. at 342 (citing King v. Hillen, 21 F.3d 1572, 1582 (Fed. Cir. 1994)). See also Leibovitz v. New York City Transit Authority, 4 F. Supp. 2d 144, 152 (E.D.N.Y. 1998) (in context of Title VII hostile environment sexual harassment claim by a woman who had not been personally harassed, the court noted that an environment in which a superior refers to women in vulgar sexual terms "is demeaning, harassing, and incompatible with the dignity and well-being of all the women in that workplace" $)$.

154. In re Walter Spagnola, 473 B.R. 518, 524 (Bankr. S.D.N.Y. 2012).

155. In the matter of Judge Edward Seaman, 627 A.2d 106, 115 (N.J. 1993). 
court of appeals held sufficient his allegations that the female guard had touched his groin and reached into his gym shorts to stroke his penis, noting that the sexual assault on an inmate by a prison guard is "'offensive to human dignity.'"156

State legislatures enacting prohibitions against sexual harassment have also drawn the connection between sexual harassment and dignity. The Tennessee Human Rights Act, which prohibits sexual harassment in the context of the workplace, includes within its purposes not only to prohibit discrimination on the basis of sex and other characteristics, but to "[p]rotect [individuals'] interest in personal dignity and freedom from humiliation." 157 Similarly, the Puerto Rico statute prohibiting sexual harassment in the context of employment declares that it is the public policy of Puerto Rico that "sexual harassment in employment is a type of sexual discrimination and, as such, constitutes an illegal and undesirable practice that goes against the established constitutional principle that the dignity of a human being is inviolable." 158

Sexual harassment implicates notions of equality, and therefore might be viewed as implicating dignity because of the denial of equal respect provided to others. But sexual harassment may also properly be perceived to be wrong because it subjects its targets to humiliating and degrading-ultimately disrespectful - conduct that is contrary to the right of the individual to be treated with the dignity that all humans deserve, even in the absence of a showing that notions of equality have also been offended.

I do not pretend to be the first to suggest that the United States seek to incorporate notions of dignity into its sexual harassment law. In her 1997 article "Treating Sexual Harassment with Respect," Professor Anita Bernstein challenges the use of reasonableness as the appropriate standard for judging sexual harassment, instead suggesting that the "respectful person" standard be substituted so that sexual harassment is seen as a form of disrespect and violation of dignity. ${ }^{159}$ But Professor Bernstein does not appear to have been advocating the use of dignity as an independent ground from discrimination for prohibiting sexual harassment, merely as a method for determining what types of harassment based on discrimination would violate Title VII's prohibition on sexual harassment. ${ }^{160}$ Under her approach, uncivil and disrespectful conduct

156. Wood v. Beauclair, 692 F.3d 1041, 1049, 1051 (9th Cir. 2012) (quoting Schwenk v. Hartford, 204 F.3d 1187, 1196 (9th Cir. 2000)).

157. TENN. CODE ANN. § 4-21-101(a)(3-4) (2006).

158. 29 P.R. LAWS ANN. tit. 29, § 155 (2009).

159. See Anita Bernstein, Treating Sexual Harassment with Respect, 111 HARV. L. REV. 445, 455-92 (1997) (critiquing the use of the reasonable person standard in sexual harassment cases as vague, hollow and gendered).

160. That Professor Bernstein does not see dignity as a substitution for, or alternative to, the concept of discrimination for actionable sexual harassment claim seems clear from her statement that:

Even when the plaintiff can clear these hurtles [summary judgment and motions to dismiss], and even when the defendant did not behave as a respectful person, a Title VII claim might fail under the respectful person standard because of its poor fit with the antidiscrimination purposes of the statute. Disrespectful conduct not based on sex would remain outside the remedial boundaries of Title VII, consistent with the view now prevailing in the courts.

Id.at 505 . 
would not be actionable merely because it was uncivil and disrespectful, but only if it was also discriminatory.

Professor Rosa Ehrenreich (Brooks) in her 1999 article "Dignity and Discrimination: Toward a Pluralistic Understanding of Workplace Harassment"161 also argued for inclusion of the concept of dignity as a ground for prohibiting sexual harassment. Her proposal was to use existing tort law to reach harassment that is not motivated by discrimination, noting that certain intentional torts, like the tort of intentional infliction of emotional distress, are largely based on notions of dignitary harm. ${ }^{162}$ She, however, is more confident than I am that the disadvantages of tort law-including a focus on individual rather than employer liability - can be overcome by public policy arguments, and that the occurrence of these torts in the workplace will be seen as an aggravating factor to allow such claims to be more easily made. ${ }^{163}$ I am skeptical that courts will interpret common law tort claims to provide substantial protection to men and women who face sexual harassment in the workplace, particularly in light of the general view expressed by a number of courts that the degree of outrageousness required for a claim of intentional infliction of emotional distress, for example, is a very difficult standard to meet in the context of the workplace because a certain amount of distress is a normal part of the workplace context. ${ }^{164}$

My proposal is more far-reaching. I am suggesting the federal statutory adoption of the concept of dignity as an independent ground for prohibiting sexual harassment, in addition to the present prohibition contained in Title VII, which is tied to discrimination. In a real sense, I am advocating the adoption of a requirement of civility and respect in the workplace. Or, rather, I am advocating a prohibition against some forms of uncivil and disrespectful conduct, which would prohibit sexual harassment even if that harassment was not linked to, or could not be shown to be linked to, a discriminatory motive on the part of the harasser or a discriminatory effect on the target of the harassment.

I am not arguing that all forms of sexually harassing conduct in the workplace that implicate dignity in some slight way be prohibited by federal law. After all, even when courts find sexual harassment to be discrimination on the basis of sex, they find it to be unlawful under Title VII only if it is sufficiently severe or pervasive to affect the terms and conditions of employment of the

161. Rosa Ehrenreich, Dignity and Discrimination: Toward a Pluralistic Understanding of Workplace Harassment, 88 GEO. L. J. 1 (1999).

162. See id. at 22-32 (explaining the concept of "dignitary harm" in modern tort law and describing the harm as an injury to "personality interests").

163. See id. at 44-60 (suggesting that, because the notion of "abuse of power," which is one factor that makes a defendant's conduct outrageous, has been interpreted broadly in sexual harassment cases involving claims for intentional infliction of emotional distress, dignitary harms in the workplace "could be seen as inherently aggravated").

164. See, e.g., Cox v. Keystone Carbon Co., 861 F.2d 390, 395 (3d Cir. 1988) ("At the outset, it must be recognized that it is extremely rare to find conduct in the employment context that will arise to the level of outrageousness necessary to provide a basis for recovery for the tort of intentional infliction of emotional distress."); Wilkinson v. Hobbs Assoc., No. CV075007485, 2011 WL 3587472, at *4 (Conn. Super. Ct. 2011) (" $[\mathrm{I}] \mathrm{t}$ is clear that individuals in the workplace reasonably should expect to experience some level of emotional distress, even significant emotional distress, as a result of conduct in the workplace.") (quoting Perodeau v. Hartford, 792 A.2d 752, 757 (Conn. 2002)). 
harassed employee. ${ }^{165}$ In the same way that discriminatory sexual harassment might be found to be "de minimus" and therefore not unlawful, sexual harassment that threatens the dignity interests of employees might also be found to be actionable only in those cases in which it is deemed to be sufficiently severe or pervasive to actually affect an employee's working conditions or workplace environment - when the affront to dignity creates a hostile, offensive, or abusive environment.

I would not, however, incorporate a requirement of unwelcomeness into this proposed prohibition of sexual harassment based on the concept of harm to dignity. Elsewhere, I have argued against the requirement of unwelcomeness for claims of sexual harassment under Title VII, on the grounds that such a requirement places an inappropriate emphasis on the conduct of the target of harassment rather than the harasser. There is simply no reason to require a showing that a woman or a man who is sexually harassed in such a way as to create an offensive or abusive working environment did not consent to, invite, or solicit that harassment, any more than it should be required that other forms of discrimination or harassment be shown to have been unwanted. ${ }^{166}$ Accordingly, I would not require a showing that sexual harassment that was sufficiently humiliating or degrading to violate the dignity of an employee was also unwanted or uninvited by the target of harassment, although in the unlikely event that a harassed employee actually wanted to be humiliated or degraded, a court might conclude that his or her dignity had not been sufficiently violated to state a cause of action.

The experience of at least one other nation in using the concept of dignity as the basis for the prohibition on sexual harassment does suggest a need for caution in relying on the concept of dignity as the primary justification for sexual harassment laws. In her article titled "Stereotyping Women, Individualizing Harassment: The Dignitary Paradigm of Sex Harassment Law Between the Limits of Law and the Limits of Feminism," Professor Noya Rimalt describes her study of court decisions interpreting Israel's Prevention of Sexual Harassment Law enacted in 1998.167 She explains how Israeli feminists looked to the European Union model of sexual harassment and its focus on dignity as a way to avoid dissatisfaction with some aspects of sexual harassment law, in particular its focus on notions of formal equality as the measure of whether discrimination had occurred. ${ }^{168}$ Even though Israel's sexual harassment statute referred to both equality and dignity as grounds for prohibiting sexual harassment, she describes

165. Harris v. Forklift Sys., Inc., 510 U.S. 17, 21-22 (1993) (“Conduct that is not severe or pervasive enough to create an objectively hostile or abusive work environment-an environment that a reasonable person would find hostile or abusive-is beyond Title VII's purview. Likewise, if the victim does not subjectively perceive the environment to be abusive, the conduct has not actually altered the conditions of the victim's employment, and there is no Title VII violation.").

166. See Gender Harassment, supra note 6, at 577-89 (reviewing the case law interpreting, and critiquing the rationales for, the "unwelcomeness" requirement).

167. Noya Rimalt, Stereotyping Women, Individualizing Harassment: The Dignitary Paradigm of Sexual Harassment Law Between the Limits of Law and the Limits of Feminism, 19 YALE J. L. \& FEMINISM 391 (2008).

168. See id. at 395-410 (reviewing the historical development of Israel's Prevention of Sexual Harassment Law). 
how courts have prioritized dignity harms over equality harms, essentially seeing sexual harassment as a harm to individual women rather than as a groupbased harm against women more generally. ${ }^{169}$ She also indicates that Israeli courts deciding cases of sexual harassment have taken a paternalistic and moralistic approach to women complaining of sexual harassment, emphasizing their need for protection and the moral failings of the men who have harassed them, ultimately stereotyping women as frail, vulnerable, and in need of protection from challenges to their modesty and honor rather than their equality. ${ }^{170}$

Professor Rimalt suggests several reasons for this negative turn of events, including the fact that equality was listed as the final of the values supporting the enactment of the sexual harassment legislation, behind dignity, liberty, and privacy. ${ }^{171}$ She also argues that the decision to criminalize sexual harassment was also partially responsible for these negative effects, because that decision meant that sexual harassment became associated with other sexual offenses, so that sexual harassment was thought of as sex activity and the fault of an individual man, rather than as associated with gender and societal inequality. ${ }^{172}$

I take seriously the potential risks of a focus on dignity as the justification for prohibiting sexual harassment to the exclusion of equality. For a number of reasons, however, I think that there is less potential danger in incorporating notions of dignity into the sexual harassment law of the United States. In Israel, the prohibition of sexual harassment is a relatively recent phenomenon, dating only from 1988. ${ }^{173}$ By contrast, in the United States, sexual harassment has been prohibited on a federal level, at least nominally, since 1965 and has been recognized as a form of sexual discrimination since the late 1970s or early 1980s. ${ }^{174}$ Accordingly, courts in the United States have generally conceived of sexual harassment in terms of discrimination; it seems unlikely that incorporating the concept of dignity as another justification for prohibiting sexual harassment will cause courts to abandon the concept of sexual harassment as discrimination entirely, although it is possible that such an action could cause less emphasis to be placed on discrimination and the aspects of sexual harassment that are both caused by and create gender inequality.

Additionally, I do not propose a criminalization of sexual harassment, as has occurred in France and in Israel, so there is less reason for courts to directly link sexual harassment with sex crimes, such as sexual assault and rape. I believe that even courts that are willing to condemn harassers civilly will be much less

169. Id. at 413 .

170. See id. at 414-41.

171. Id. at 442. The Israeli sexual harassment statute indicated that its objective was "to prohibit sexual harassment, in order to protect human dignity, liberty and privacy and in order to promote equality between the sexes." Prevention of Sexual Harassment Law, 5758-1998, SH No. 166 p. 1.

172. See Rimalt, supra note 167, at 442-44 (also noting that the association between sexual harassment and other sex crimes "allowed a moralistic conceptualization to dominate the dignitary harm of harassment," diverting attention to "women's honor," among other unintended consequences of criminalization).

173. Id. at 401-02.

174. For discussion of the evolution of the law of sexual harassment as a form of sex discrimination, see Hébert, supra note 5, at 439-47. 
likely to impose criminal sanctions on those harassers; accordingly, I believe that criminalization of sexual harassment in a number of nations has contributed to the underenforcement of those sexual harassment laws, a result I would not like to see occur - or worsen - in the United States.

One might reasonably ask whether my proposal goes far enough. After all, I am not proposing (in this article) that all forms of harassment be included within this proposed statutory prohibition on sexual harassment based on the concept of sexual harassment as a violation of dignity. I am not proposing (in this article) the adoption in the United States of a federal statutory claim similar to a claim of moral harassment in France or a claim of "bullying," as has been advocated by Professor David Yamada in numerous publications. ${ }^{175}$ One might reasonably argue that if sexual harassment is to be prohibited not only because it is discriminatory but also because it violates the dignity rights of harassed employees, why other forms of harassment that are injurious to employees' dignity should not also be prohibited.

I am sympathetic to those concerns, but am not yet ready to take on the general hostility of American employers to the imposition of a "general civility code," even though I am generally in favor of civility in the workplace and do not see the same risks that others do in requiring that employers be civil to their employees, or at least that they refrain from certain types of uncivil behaviorgenerally behavior that is degrading and humiliating and would violate the dignity interests of those employees. Instead I am making a more modest proposal: that conduct that is already often prohibited in the workplacesexually humiliating and degrading conduct that is severe or pervasive enough to create a hostile, abusive, or offensive environment for the employees subjected to that conduct-be found to be unlawful when it violates the dignity of the harassed employee, regardless of what is found to have motivated that conduct. That is, the law should equally prohibit such sexually humiliating and degrading conduct, whether the conduct is undertaken because a supervisor or co-worker does not like women (or men) in general, because the supervisor or co-worker does not like women (or men) in a particular job or position, because the supervisor or co-worker does not like this particular woman or man, or because of some other reason. The harm of sexually humiliating and degrading conduct should be recognized as harmful to the dignity of employees, regardless of whether the courts recognize that the equality interests of employees may also be implicated.

\section{CONCLUSION}

For much of its history, France's law concerning sexual harassment has been narrower and more restrictive than the sexual harassment law of the United States, but, unlike the United States' prohibition of sexual harassment, France's prohibition has not been focused on the concept of discrimination. Recently, France appears to have significantly broadened its prohibition on sexual harassment, as part of its reenactment of a provision of the Penal Code that was

175. E.g., David C. Yamada, Workplace Bullying and American Employment Law: A Ten-Year Progress Report and Assessment, 32 COMP. LAB. L. \& POL'Y J. 251 (2010). 
declared unconstitutional by the Constitutional Council. Influenced by the European Union Directives on harassment, France has incorporated the concept of violation of dignity into its prohibition on sexual harassment, so that degrading and humiliating conduct of a sexual nature can constitute sexual harassment when that conduct results in a violation of an individual's dignity.

In this article, I have argued that the United States should take a lesson from the French law of sexual harassment-and should broaden its notion of sexual harassment beyond just a form of discrimination to also recognize that sexual harassment, even if not established as discriminatory in nature, should be prohibited precisely because sexually harassing conduct is degrading and humiliating, and therefore offensive to and violative of human dignity. I have argued that the concept of dignity be recognized as an alternative and independent ground for condemning sexual harassment under federal statutory employment law. I have argued that sexual harassment should be prohibited even if it is divorced from sex. 